
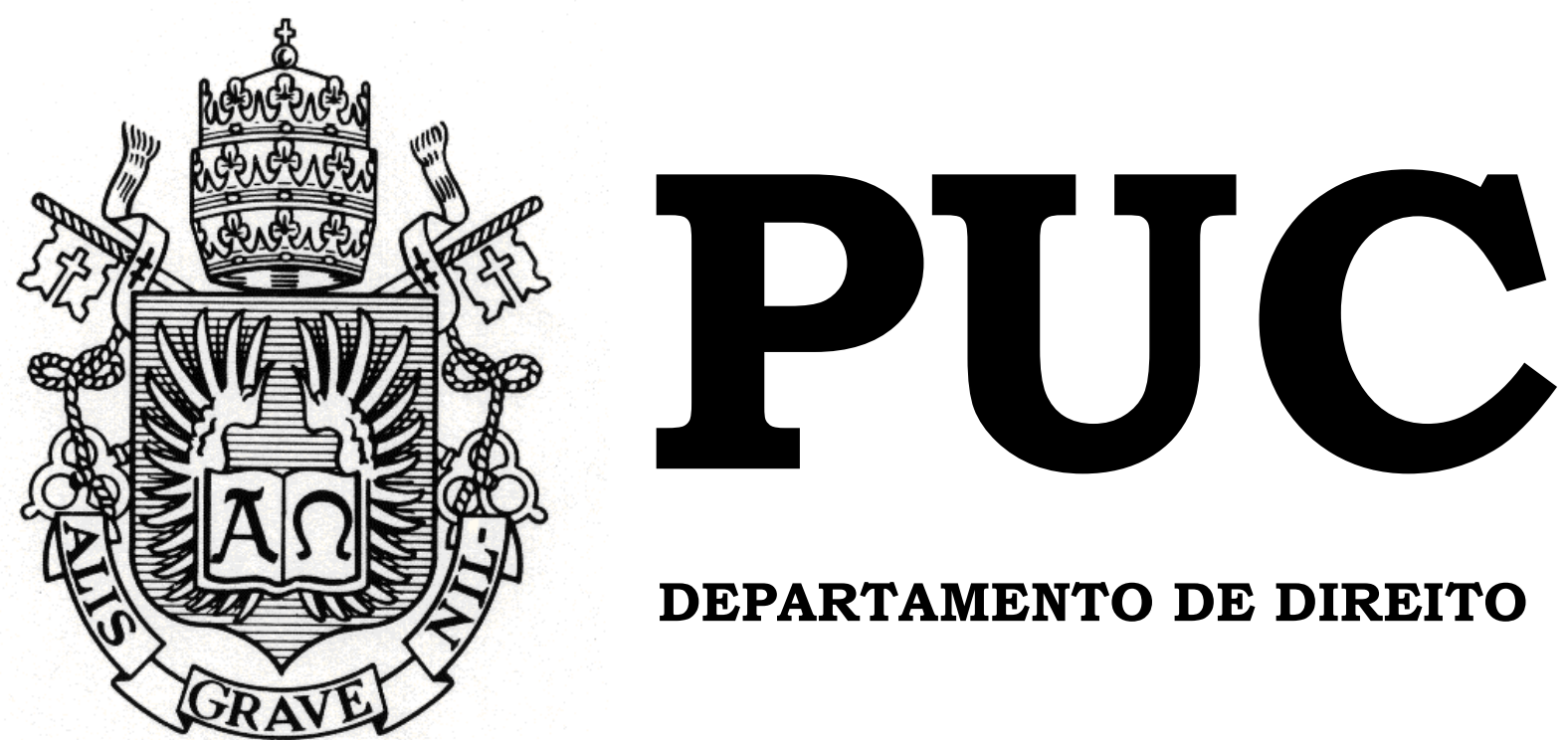

DEPARTAMENTO DE DIREITO

\title{
A DESOBEDIÊNCIA CIVIL COMO EXERCÍCIO DO DIREITO DE RESISTÊNCIA
}

Por

TATIANE SANTOS DE SOUZA

ORIENTADORA: Prof ${ }^{a}$. Ana Luiza Saramago Stern

2018.2

PONTIFÍCIA UNIVERSIDADE CATÓLICA DO RIO DE JANEIRO

RUA MARQUÊS DE SÃO VICENTE, 225 - CEP 22453-

900

RIO DE JANEIRO - BRASIL 


\title{
A Desobediência Civil como Exercicio do Direito de Resistência
}

\author{
por \\ TATIANE SANTOS DE SOUZA
}

Monografia apresentada ao Departamento de Direito da Pontificia Universidade Católica do Rio de Janeiro (PUC-Rio) para a obtenção do Título de Bacharel em Direito.

Orientadora: Prof ${ }^{a}$. Ana Luiza Saramago Stern 


\section{Agradecimentos}

Agradeço à minha amada mãe, Ivone, a qual sempre me ofereceu amor e carinho; e por seus sempre sábios conselhos, em especial ao que permitiu escolher a profissão a seguir. Pelo companheirismo e amizade em sempre levantar-se comigo em todas as madrugadas de frio; e em não se deitar antes que eu estivesse no conforto do lar nas voltas das aulas noturnas.

Agradeço ao meu pai, Wilson, que sempre torceu pelas minhas conquistas e me ofereceu todo o suporte que precisei nessa trajetória de estudo.

Agradeço aos meus queridos irmãos, Olga e Vitor. Olga, que sempre me inspira com sua singular sabedoria; e Vitor, que sempre me contagia com sua singular alegria.

Agradeço ao meu noivo, Lucas, que com carinho sempre me apoiou.

Agradeço à minha orientadora, Ana Luiza, por me orientar desde o PIBIC, por me escolher como integrante de seu grupo de pesquisa. Agradeço pela disponibilidade e acessibilidade em sua orientação.

Agradeço aos professores do Departamento de Direito PUC-Rio, pelos ensinamentos e debates sempre ricos e construtivos.

Agradeço aos meus amigos, pela companhia diária, pelos conselhos, pela inspiração e incentivo. Em nome de todos, os mais próximos, Michele, Mariana, Lucas, Carol, Aline, Matheus, Dayane, Maria, Nathalia e Fernanda. 


\section{Resumo}

O presente estudo, sem pretensão de esgotar o tema, visa apresentar o instituto do direito de resistência, com ênfase na desobediência civil, que é uma das formas de seu exercício. Ainda, se propõe a analisar a previsão do ius resistendi no ordenamento brasileiro, a partir da interpretação do texto constitucional. Sendo identificado a objeção de consciência e a greve política como formas de exercício explicitamente previstos na constituição e a desobediência civil como uma forma implicitamente prevista. Para tanto o presente estudo se debruçou em conhecer e apresentar acerca do direito de resistência e seus preceitos conceituais e filosóficos principalmente por meio de John Locke e Thomas Jefferson. De igual modo, buscar-se-á trazer sobre os pontos cardeais da desobediência civil, por meio da historicidade e remontando os grandes nomes expoentes do presente instituto como Henry David Thoreau, Martin Luther King e Mahatma Gandhi. Por fim, buscar-seá analisar os preceitos supracitados com o ordenamento jurídico brasileiro, buscando trazer os direitos e garantias para aplicações práticas dos referidos institutos supramencionados.

Palavras-chave: Direito de Resistência. Desobediência Civil. Direito de Resistência no Ordenamento Jurídico Brasileiro. 


\section{Abstract}

The present study, without pretension to exhaust the subject, aims to present the institute of the right of resistance, with emphasis in the civil disobedience, that is one of the forms of its exercise. Still, it proposes to analyze the prediction of the ius resistendi in the Brazilian legal system, from the interpretation of the constitutional text. Conscientious objection and political strike are identified as forms of exercise explicitly foreseen in the constitution and civil disobedience as an implicitly foreseen form. To this end, the present study has focused on knowing and presenting about the right of resistance and its conceptual and philosophical precepts mainly through John Locke and Thomas Jefferson. In the same way, it will be sought to bring about the cardinal points of civil disobedience, through historicity and tracing the great exponents of the present institute as Thoreau, Martin Luther King and Mahatma Gandhi. Finally, we will seek to analyze the above-mentioned precepts with the Brazilian legal system, seeking to bring the rights and guarantees for practical applications of the abovementioned institutes.

Keywords: Right of resistance. Civil disobedience. Right of resistance in Brazilian legal system. 
"O que é surpreendente não é que os povos se revoltem, mas sim que não se revoltem."

(Wilhelm Reich)

"Os jovens de hoje não sabem o que significa liberdade, e isto é triste."

(Allen Ginsberg)

"O fato de em todas as épocas ter existido a escravidão, desmente a tendência a considera-la coisa do passado”.

(João Quartim de Moraes)

"Se a lei contiver erros de tal ordem que nos obrigue a ser um instrumento de injustiça para alguém, e se somente for este o caso, então eu digo, viole a lei”.

(Henry David Thoreau) 


\section{SUMÁRIO}

Introdução ......................................................................................................................... 8

1. SOBRE O DIREITO DE RESISTÊNCIA .........................................11

1.1 Apontamentos Iniciais ........................................................................ 11

1.2 Apontamentos Históricos .................................................................... 17

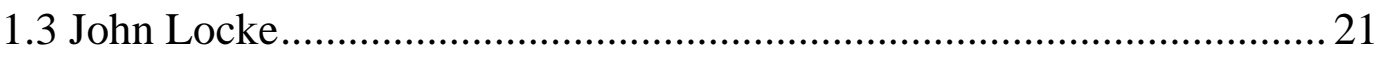

1.3.1 O Contratualismo Lockeano ............................................................... 22

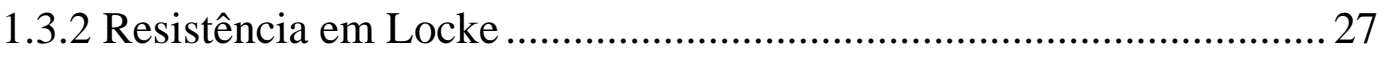

1.4 O Dever de Resistência em Thomas Jefferson ......................................... 31

1.5 Conclusão do Capítulo .............................................................................. 34

2. SOBRE A DESOBEDIÊNCIA CIVIL ..............................................36

2.1 Apontamentos Gerais Sobre a Desobediência Civil................................ 36

2.2 Henry David Thoreau: O Exercício individual da Desobediência Civil39

2.3 Mahatma Gandhi: A Não Violência ......................................................... 43

2.4 Martin Luther King Jr.: o Exercício Coletivo da Desobediência Civil . 46

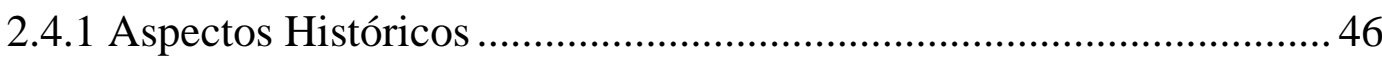

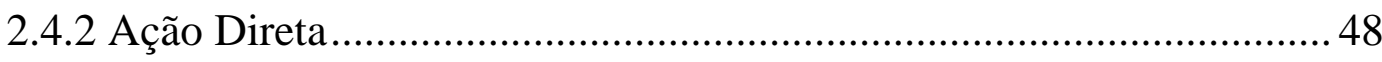

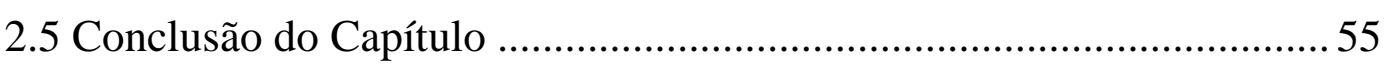

\section{O DIREITO DE RESISTÊNCIA E A DESOBEDIÊNCIA CIVIL} NO ORDENAMENTO JURÍDICO BRASILEIRO................................57

3.1 Direitos e Garantias Fundamentais na Constituição Brasileira de 198858

3.2 Análise do Direito de Resistência no Brasil ............................................ 65

3.2.1 Direito de Resistência Explícito na Constituição ................................... 67

3.2.2 A Desobediência Civil como Direito Implícito na Constituição......... 74

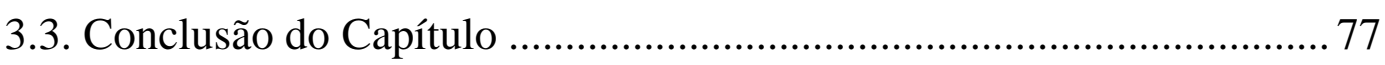

CONCLUSÃO

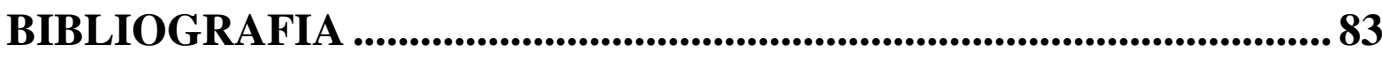




\section{Introdução}

Ante a importância do instituto do direito de resistência, sobremaneira a desobediência civil, como instrumento apto a proteção das garantias e direitos fundamentais e a afastar as arbitrariedades estatais e a manutenção da democracia, o presente estudo toma como objeto os aspectos históricos do direito de resistência; os apontamentos gerais acerca da desobediência civil; e o instituto do direito de resistência no ordenamento jurídico brasileiro.

Inicialmente são abordados alguns aspectos gerais do instituto do direito de resistência. Conforme será demonstrado, o direito de resistência pode ser definido como o direito que todas as pessoas possuem de se insurgir ou resistir contra atos e fatos emanados do poder estatal que ponham em perigo seus direitos fundamentais, bem como ameacem o Estado Democrático de Direito. Para Locke, o ius resistendi é um direito natural, anterior ao Estado político. Segundo o autor inglês, uma vez que existe já nos primórdios do estado de natureza, tal direito deve ser mantido e respeitado na sociedade política. ${ }^{1}$ No entanto, Locke não é o único a tratar do direito de resistência.

Aqui também trataremos sobre o dever de resistência de Thomas Jefferson, um dos autores da célebre Declaração de Independência dos Estados Unidos. Embora Thomas Jefferson também seja um contratualistas, e sua teoria possua algumas similitudes com a teoria Lockeana, há também algumas particularidades. Ante a contribuição teórica de diversos autores para a construção da doutrina do ius resistendi, este está longe de ser um instituto homogêneo, sendo-lhe atribuídas variadas concepções para sua definição.

Considerando o direito de resistência como gênero, este apresenta as seguintes espécies (formas) de manifestação, segundo José Carlos

\footnotetext{
${ }^{1}$ LOCKE, John. Segundo Tratado Sobre o Governo Civil. Tradução: Marsely de Marco Dantas. São Paulo: EDIPRO, 2014.
} 
Buzanello: objeção de consciência, greve política, desobediência civil, direito à autodeterminação dos povos, direito à revolução e direito à guerra. $^{2}$

Não obstante o direito de resistência apresentado por Locke e por Jefferson, seja instrumento apto para se enfrentar os arbítrios estatais, a utilização desse direito a partir do desenvolvido por estes autores exigia a manifestação de vontade da maioria. Dessa forma, segundo esta concepção do direito de resistência as minorias enfrentariam dificuldades para verem suas pautas atendidas, uma vez que, para isso, precisariam de apoio da maioria.

Ante o exposto, no segundo capítulo é apresentado como o modo de exercício do direito de resistência sofreu grandes modificações com a contribuição de Henry David Thoreau. O autor de "Desobediência Civil" introduziu a ideia de que o ius resistendi pode ser exercido individualmente ou por pequenos grupos. Sendo a principal característica dessa espécie do direito de resistência a previsão do indivíduo poder insurgir-se contra os abusos do Estado de modo pacífico. Logo, fica clara a importância do exercício da desobediência civil para a efetivação e aperfeiçoamento da ordem jurídica posta.

Neste sentido, na afirmação desta forma de exercício do direito de resistências, imperioso se faz mencionar: Mahatma Gandhi, que ficou mundialmente conhecido pelo seu engajamento pacifista na busca pela efetivação dos direitos civis e políticos dos indianos, bem como por dedicar a sua vida em função do processo de formação do Estado indiano. ${ }^{4}$ Neste mesmo sentido cabe ainda citar Martin Luther King Jr. que foi um pastor e ativista norte americano do século XX.

Influenciado pela obra "Desobediência Civil" de Henry David Thoreau e pelos escritos de Mahatma Gandhi (líder indiano claramente

\footnotetext{
${ }^{2}$ BUZANELlO, José Carlos. Direito de Resistência Constitucional. Rio de Janeiro: América Jurídica, 2002, p.135.

${ }^{3}$ Título dado ao seu discurso The right and duties of the individual in relation to government.

${ }^{4}$ COSTA, Nelson Nery. Ciência Política. $3^{\text {a }}$. edição. Rio de Janeiro: Forense, 2012, p. 573/574.
} 
influenciados por Henry David Thoreau e Leon Tolstoi), Martin Luther King ficou conhecido pela sua luta pelos direitos civis dos negros nos Estados Unidos tendo, inclusive, recebido o Prêmio Nobel da Paz de 1964 por conta do movimento pacífico contra o preconceito racial que liderou.

Sob o compromisso de examinar a conjuntura do instituto do direito de resistência, e identificar o exercício da desobediência civil no ordenamento pátrio, no terceiro capítulo são tratados os modos de exercício do direito de resistência previstos no texto constitucional, e admitidos no ordenamento jurídico brasileiro.

Mister se fez apontar as promessas da Constituição da República Federativa do Brasil de 1988 acerca dos direitos e garantias fundamentais; uma vez que a desobediência civil pode ser compreendida como direito fundamental, conforme entendimento adotado por José Carlos Buzanello ${ }^{5} \mathrm{e}$ Maria Garcia ${ }^{6}$. Assim, a objeção de consciência e a greve política são identificados como modos de exercício do direito de resistência previstos explicitamente na CRFB88; e a desobediência civil como modo implícito.

\footnotetext{
5 BUZANELlo, José Carlos. Direito de Resistência Constitucional. Rio de Janeiro: América Jurídica, 2002.

${ }^{6}$ GARCIA, Maria. Desobediência civil: direito fundamental. São Paulo: Editora Revista dos Tribunais, 2004, p. 298.
} 


\section{SOBRE O DIREITO DE RESISTÊNCIA}

O debate sobre o direito de resistência desde seu surgimento contou com o arcabouço teórico de diversos autores que contribuíram com suas obras para a construção do ius resistendi, um instituto filosófico, sociológico, político e jurídico. Por consequência, a doutrina do direito de resistência está longe de ser homogênea, sendo-lhe atribuídas variadas concepções para sua definição e fundamentação, além disso, as questões suscitadas pelos teóricos são controvertidas.

Como veremos, os autores, ora analisados, ao iniciarem sua abordagem acerca do tema da resistência, debruçaram-se sobre os apontamentos históricos de criação e formação do Estado, da relação do indivíduo com o Estado político, e os fundamentos jurídicos que possam justificar o seu reconhecimento. Em razão da inexistência de consenso doutrinário acerca destas temáticas, são suscetíveis diversos tipos de abordagens acerca do ius resistendi.

\subsection{Apontamentos Iniciais}

O direito de resistência possui estrita ligação com à relação de poder existente entre cada indivíduo e o Estado, logo, sem dificuldade, é possível inferir que suas definições e características estão relacionadas com a época e espaço territorial em que são tratados. Para a doutrina tradicional são três os elementos constitutivos do Estado: território (elemento físico), povo (elemento humano) e poder/soberania (elemento subjetivo). ${ }^{7} \mathrm{O}$ escritor Hans Kelsen ainda se utiliza de um quarto elemento, o tempo, que leva em consideração o período de existência daquele Estado. ${ }^{8}$ Já Dalmo de Abreu

\footnotetext{
${ }^{7}$ FRIED, Reis. Curso Analítico de Direito Constitucional e de Teoria Geral do Estado. Rio de Janeiro: Forense, 2005, p. 119.

${ }^{8}$ KELSEN, Hans.Teoria geral do direito e do Estado. São Paulo: Martins Fontes,2000, p. 314-315.
} 
Dallari acrescenta como quarto elemento constitutivo do Estado, a finalidade, ${ }^{9}$ a qual relaciona-se com os fins almejados pelo ente público. ${ }^{10}$

Embora o elemento povo seja comumente utilizado como sinônimo de população e nação, com estes não se confunde. O termo população não tem sentido jurídico mas sim demográfico, trata de expressão numérica das pessoas que vivem no território de um Estado ou nele se encontrem temporariamente. ${ }^{11}$ Já a nação, segundo Miguel Reale, indica a comunhão oriunda de laços históricos e culturais, ${ }^{12}$ qualificando uma situação jurídica de pertencimento a uma comunidade histórico-cultural. ${ }^{13}$ Sendo o povo definido como o conjunto de nacionais de um país, formado por todos aqueles que com ele detêm um vínculo político-jurídico de caráter permanente, participando da vontade do Estado e do exercício de poder soberano. $^{14}$

O território é a área contida dentro das fronteiras de um Estado, bem como todo o espaço territorial em que o Estado pode exercer sua soberania e, consequentemente, aplicar o seu Direito. Para Dallari a soberania, tratada pelo autor como imperium, é o que dá a qualificação das relações do Estado com o seu território, o qual manifesta-se no exercício de poder sobre as pessoas que nele estão de modo que assim estabelece-se o poder sobre o território. $\mathrm{O}$ autor conceitua a soberania de duas maneiras distintas: como sinônimo de independência do povo de dado Estado que não se submete aos mandos de nenhum outro; e como o poder jurídico mais alto significando que dentro dos limites de jurisdição de um Estado é o poder supremo acima do qual nenhum outro se encontra, tendo assim o poder de decisão em última instância. ${ }^{15}$

\footnotetext{
${ }^{9}$ DALLARI, Dalmo de Abreu. Elementos de Teoria Geral do Estado. São Paulo: Saraiva, 2003, p. 71-72.

${ }^{10}$ Ibid. p. 102.

${ }^{11}$ Ibid. p. 95.

${ }^{12}$ MIGUEL, Reale. Teoria do Direito e do Estado. São Paulo: Martins, 1960, p. 103 apud

DALLARI, Dalmo de Abreu. Elementos de Teoria Geral do Estado. São Paulo: Saraiva, 2003, p. 96.

${ }^{13}$ Ibid. p. 95.

${ }^{14}$ Ibid. p. $99-100$.

${ }^{15}$ Ibid. p. $74-84,87-88$
} 
Sem abrir mão dos elementos tradicionalmente atribuídos como constitutivos do Estado, Dalmo de Abreu Dallari conceitua Estado como a "ordem jurídica soberana que tem por fim o bem comum de um povo situado em determinado território". ${ }^{16}$

A partir do que foi dito é possível afirmar que o Estado deve atuar em benefício da sociedade através do exercício do poder soberano que possui, e o indivíduo the deve obediência. Por conseguinte, é um dever obedecer às ordens emanadas dos órgãos estatais quando justas, mas e quanto às ordens injustas? Como agir diante daquelas ordens contrárias aos interesses do povo? A professora Maria Garcia, em sua obra "Desobediência Civil: Direito Fundamental", ao tratar do direito de resistência, põe em análise a seguinte questão "podemos desobedecer?". ${ }^{17}$ Celso Lafer entende que o cerne do debate do direito de resistência gira em torno da relação "governantes x governados"18. Uma vez que, na mesma esteira em que os governantes podem reivindicar o direito de serem obedecidos, os cidadãos podem reivindicar o direito de serem governados de forma sábia e sob a égide de leis justas. ${ }^{19}$

Segundo a autora Maria Garcia, a partir da recusa à obediência, é possível observar três aspectos: a oposição às leis injustas, a resistência à opressão e a revolução. ${ }^{20}$ Maria Garcia ainda elucida que, para o renomado jurista Machado Paupério, a resistência à opressão identifica-se pelo sentimento de revolta. Sentimento que se origina quando os governantes violam o direito do qual surge o Poder, cujas prerrogativas eles exercem. Para o autor, na resistência à opressão, está em exame a atitude dos

\footnotetext{
${ }^{16}$ Ibid. p. 118.

${ }^{17}$ GARCIA, Maria. Desobediência civil: direito fundamental. São Paulo: Editora Revista dos Tribunais, 2004, p.153.

${ }^{18}$ LAFER, Celso. A Reconstrução dos Direitos Humanos: um diálogo com o pensamento de Hannah Arendt. São Paulo: Companhia das Letras,1991. p. 188.

${ }^{19}$ Ibid. p. 188.

20 "Frequentemente as sanções jurídicas organizadas contra o abuso do poder não são suficientes para conter a injustiça da lei ou dos governantes, pois estes, quando extravasados de seus naturais limites, muitas vezes não podem ser contidos por normas superiores que já não respeitam. Por isso reconhece-se aos governados, em certas condições, a recusa da desobediência" - PAUPÉRIO, Machado. O direito político de resistência. Rio de Janeiro: Forense, 1978, p. 11-13 apud GARCIA, Maria. Desobediência civil: direito fundamental. São Paulo: Editora Revista dos Tribunais, 2004, p.157.
} 
governantes por correlação com a ideia de direito que legitima sua autoridade. $^{21}$

A partir dos apontamentos iniciais realizados podem surgir os seguintes questionamentos: O que é o direito de resistência? Quais os limites de seu exercício? De que forma exercê-lo? Como se demonstrará neste trabalho, em que pese o dissenso doutrinário, o ius resistendi pode ser definido como o direito que todas as pessoas possuem, onde quer que se encontrem, de se insurgir e/ou resistir contra atos e fatos emanados do poder estatal que ponham em perigo seus direitos fundamentais.

Nos dizeres de Canotilho, os direitos fundamentais:

(...) cumprem a função de direitos de defesa dos cidadãos sob uma dupla perspectiva: (1) constituem, num plano jurídicoobjectivo, normas de competência negativa para os poderes públicos, proibindo fundamentalmente as ingerências destes na esfera jurídica individual; (2) implicam, num plano jurídicosubjectivo, o poder de exercer positivamente direitos fundamentais (liberdade positiva) e de exigir omissões dos poderes públicos, de forma a evitar agressões lesivas por parte dos mesmos (liberdade negativa). ${ }^{22}$

Para Norberto Bobbio o direito de resistência pode ser definido como o recurso ao uso da força como aplicação do direito de legítima defesa ${ }^{23}$ :

(...)um direito secundário, do mesmo modo como são normas secundárias as que servem para proteger as normas primárias: é um direito secundário que intervém num segundo momento, quando são violados os direitos de liberdade, de propriedade e de segurança, que são direitos primários. ${ }^{24}$

Assim, como direito secundário, o exercício do direito de resistência será legítimo se praticado em último caso, após esgotadas todas as outras possibilidades de ter seus direitos resguardados.

Esse entendimento se assemelha ao adotado pelo doutrinador José Gomes Canotilho que elenca o direito de resistência entre os meios de

${ }^{21}$ Ibid. p. 157.

${ }^{22}$ CANOTILHO, José Joaquim Gomes. Direito constitucional e Teoria da Constituição. $6^{\mathrm{a}}$ Edição. Coimbra: Almedina, 1993, p. 541.

${ }^{23}$ BOBBIO, Norberto; MATTEUCCI, Nicola; PASQUINO, Gianfranco. Dicionário de Política. Coordenação da Tradução João Ferreira. 11ª.ed. Brasília: Editora UNB, 1997, p. 73.

${ }^{24}$ Id., A Era dos Direitos. Tradução Carlos Nelson Coutinho. Nova ed. 7ª. Reimpressão. Rio de Janeiro: Elsevier, 2004, p. 43. 
defesa não jurisdicionais, enxergando-o como ultima ratio do cidadão que se vê ofendido nos seus direitos, liberdades e garantias, seja por atos do poder público ou por atos de entidades privadas ${ }^{25}$.

Para o autor português sua utilização será pertinente quando não houver outro meio ou modo de proteger um direito primário, fundamental e essencial ao homem, como por exemplo, a vida e a dignidade humana. ${ }^{26}$

José Carlos Buzanello também se dedica ao estudo deste tema ${ }^{27}$. O autor entende que a resistência não possui uma identidade ou forma jurídica definida (exceto quanto aos fundamentos requeridos, quais sejam, jurídicos, políticos e morais), e ainda, que o ius resistendi, se apresenta como um direito não formalizado, escapando aos arquétipos da dogmática jurídica. ${ }^{28}$ Buzanello, diante das diversas definições existentes para o termo "direito de resistência", cria e estabelece uma conceituação operacional, a fim de otimizar o desequilíbrio teórico existente ${ }^{29}$.

$\mathrm{O}$ autor define o direito de resistência em um sentido político (capacidade das pessoas, individualmente ou em grupos, se recusarem ao cumprimento de determinada obrigação jurídica, por força de razões jurídicas, política ou morais); e em um sentido jurídico (quando na esfera constitucional são qualificados gestos que indiquem enfrentamento, por ação ou omissão, do ato injusto das normas jurídicas, dos governantes, do regime político e também de terceiro). ${ }^{30}$

A fim de demonstrar as variadas contribuições do instituto do direito de resistência, podemos ainda contar com os ensinamentos do teórico filósofo Baruch Espinosa (1632-1677). O filósofo através de sua obra fundamental - Ética (1677) - insere-se num debate revolucionário para sua época. O pensamento espinosano não se funda na religiosidade cristã,

\footnotetext{
${ }^{25}$ CANOTILHO, José Joaquim Gomes. Direito constitucional e Teoria da Constituição. $6^{\mathrm{a}}$ Edição. Coimbra: Almedina, 1993, p. 663.

${ }^{26}$ Ibid. p. 663.

${ }^{27}$ BUZANELLO, José Carlos. Direito de Resistência Constitucional. Rio de Janeiro: América Jurídica, 2002, p. 112.

${ }^{28}$ Ibid. p. 112.

${ }^{29}$ Ibid. p. 112.

${ }^{30}$ Ibid. p. 113-114.
} 
calcada na existência de um Deus transcendente, como era prática entre os filósofos do período, ao contrário, sua teoria baseia-se na imanência absoluta $^{31}$. Seu pensamento ontológico, epistemológico, antropológico e ético rompe com os ideais religiosos predominantes oferecendo uma análise da gênese campo e da obediência política.

Para Espinosa tudo que existe na natureza possui intrinsicamente um esforço por perseverar na existência. Logo, tudo que existe esforçar-se para que continue existindo. É esforço positivo que busca sempre a sua perseverança na existência e nunca a destruição.

(Proposição 6, Parte III) "Cada coisa esforça-se, tanto quanto está em si, por perseverar em seu ser. E nenhuma coisa tem em si algo por meio do qual possa ser destruída, ou seja, que retire a sua existência (pela prop. 4); pelo contrário, ela se opõe a tudo que possa retirar a sua existência (pela prop. prec.). E esforçase, assim, tanto quanto pode e está em si, por perseverar em seu ser. C. Q. D."32

Uma vez que o conatus espinosano é o esforço positivo existente em cada indivíduo, o qual sempre irá buscar perseverar na existência de cada pessoa, vai sempre inclinar-se pela liberdade e pela obediência a própria liberdade. Logo, a servidão só é possível quando o conatus padecer de causas externas. Deste modo, fica claro que o campo político de Espinosa ideal é o regido pela democracia, pois somente na democracia a multidão pode ser guiada pela própria liberdade, a partir da manifestação puramente de seu conatus, sem interferência de causas externas.

Além disso, também existem variadas concepções quanto à classificação do direito de resistência. Segundo Norberto Bobbio "o direito de resistência é gênero do qual a desobediência civil, a objeção de consciência, a greve política, o direito à revolução e o princípio da autodeterminação dos povos são espécies"33.

\footnotetext{
${ }^{31}$ Para Espinosa Deus não é a figura transcendente concebida pelo cristianismo, mas sim natureza infinita sendo e estando em tudo o que há, em todas as coisas. (Proposição XI da Parte I da Ética). Spinoza, Baruch. Ética. Tradução de Tomaz Tadeu. Belo Horizonte: Autêntica Editora, 2009.

${ }^{32}$ Spinoza, Baruch. Ética. Tradução de Tomaz Tadeu. Belo Horizonte: Autêntica Editora, 2009.

${ }^{33}$ BOBBIO, Norberto. Teoria geral da política: a filosofia política e as lições dos clássicos. 5. Ed. Rio de Janeiro: Campus, 2000. P. 225, apud MIRANDA, Daniel Moreira. Introdução: Pensamento
} 
José Carlos Buzanello partilha do mesmo entendimento, no entanto, ainda acrescenta o direito à guerra como uma das espécies do direito de resistência. ${ }^{34}$

\subsection{Apontamentos Históricos}

São necessários alguns apontamentos históricos para o debate do ius resistendi. No entanto, cabe aqui observar que não é objeto do presente trabalho discorrer longamente acerca dos dados históricos da doutrina do direito de resistência. Nosso objetivo é destacar que mesmo nas aparições mais antigas de que se tem relato o direito de resistência já se mostrava como a forma dos indivíduos reagirem às arbitrariedades estatais.

Embora também paire o dissenso doutrinário acerca da primeira aparição do termo direito de resistência, bem como dos debates acerca desta temática, Machado Paupério, em busca de delinear as raízes históricas do ius resistendi menciona o Código de Hamurabi que previra a rebelião como castigo ao mau governante que não respeitasse os mandamentos e as leis. ${ }^{35}$

O referido código, datado de cerca de dois mil anos antes de Cristo, é apontado como o documento jurídico mais antigo de que se tem registro. ${ }^{36}$

$\mathrm{Na}$ Grécia Antiga, ressalta-se o registro de Sófocles. Nelson Nery Costa aponta que foi em Antígona, tragédia Grega de Sófocles, produzida por volta de 442 a.c., em que primeiro se falou do direito de resistência ${ }^{37}$. Antígona é a última peça da obra que ficou conhecia como "Trilogia Tebana", na qual Sófocles registrou que "há certas leis não escritas, superiores a todas as outras, pelas quais não é vedado desobedecer às

Político de Thoreau. In: THOREAU, Henry David. A desobediência civil. Tradução: Daniel Moreira Miranda. São Paulo: EDIPRO, 2016, p.18.

${ }^{34}$ BUZANELLO, José Carlos. Direito de Resistência Constitucional. Rio de Janeiro: América Jurídica, 2002, p.135.

${ }_{35}$ PAUPÉRIO, Machado. O direito político de resistência. Rio de Janeiro: Forense, 1978, apud GARCIA, Maria. Desobediência civil: direito fundamental. São Paulo: Editora Revista dos Tribunais, 2004, p.158.

${ }^{36}$ CARRILHO, Cristiano. Manual de História dos Sistemas Jurídicos. Rio de Janeiro: Elsevier, 2009 , p.16.

${ }^{37}$ COSTA, Nelson Nery. Ciência Política. $3^{\text {a }}$. edição. Rio de Janeiro: Forense, 2012, p. 65. 
demais, quando com elas colidentes"38. Estas leis seriam advindas dos deuses - referindo-se ao direito natural - que teriam o condão de delimitar o poder do soberano, uma vez que a lei dos homens não poderia contrariá-las. Deste modo, toda vez que qualquer determinação pautada nas leis terrenas com elas colidisse, poderiam ser desobedecidas.

A peça conta que após dois dos irmãos de Antígona (Etéocles e Polinice) lutarem pelo trono de Tebas e morrerem em batalha, Creonte, tio de Antígona, toma o poder. Embora tenha concedido a Etéocles todas as honras de uma sepultura, não o fez a Polinice, a ele proibindo o sepultamento realizado por qualquer cidadão, bem como que the fosse prestado qualquer homenagem. Antígona revolta-se contra o decreto do rei Creonte e decide oferecer um sepultamento digno a seu irmão.

Para Antígona as leis naturais emanadas dos deuses são anteriores e superiores a lei posta pelo rei, estando além de qualquer governo de qualquer época. Diante deste conflito entre a lei dos homens e dos deuses, Antígona opta por esta, desobedece ao rei e tenta enterrar seu irmão, sendo em razão de seu ato condenada à morte.

Vejamos um trecho da peça que representa o diálogo entre Antígona e Creonte:

Creonte: E apesar disso, tiveste a audácia de desobedecer a essa determinação?Antígona: Sim, porque não foi Júpiter que a promulgou; e a Justiça, a deus que habita com as divindades subterrâneas, jamais estabeleceu tal decreto entre os humanos; nem eu creio que teu édito tenha força bastante para conferir a um mortal o poder de infringir as leis divinas, que nunca foram escritas, mas são irrevogáveis; não existem a partir de ontem, ou de hoje; são eternas, sim! (...) Que vou morrer, eu bem sei; é inevitável; e morreria mesmo sem a tua proclamação. E, se morrer antes do meu tempo, isso será, para mim, uma vantagem, devo dizê-lo! Quem vive, como eu, no meio de tão lutuosas desgraças, que perde com a morte? Assim, a sorte que me reservas é um mal que não se deve levar em conta; muito mais grave teria sido admitir que o filho de minha mãe jazesse sem sepultura; tudo o mais me é indiferente! Se te parece que

\footnotetext{
${ }^{38}$ GARCIA, Maria. Desobediência civil: direito fundamental. São Paulo: Editora Revista dos Tribunais, 2004, p.158.
} 
cometi um ato de demência, talvez mais louco seja quem me acusa de loucura! $!^{39}$

Para José Carlos Buzanello, resistir à opressão foi e continua sendo um grande desafio para a humanidade, uma vez que constam registros históricos de resistência antiga, medieval, moderna e até na atualidade. $\mathrm{O}$ autor afirma que, em regra, na antiguidade, bem como na idade média, utilizava-se o conceito de direito de resistência análogo ao adotado na modernidade.

Relaciona-se o ius resistendi ao "contrapoder político" 40 , dando a percepção de que desde sempre a resistência foi vista como a forma de agir contra o poder político do Estado.

Neste diapasão, deve-se atentar para o fato de que o direito de resistência, para essa corrente, só pode ser discutido dentro de um Estado constituído, fazendo da sociedade política condição sine qua non para a discussão da resistência, que gira em torno da problemática relação "Estado x indivíduo".

Os autores antigos partem da ideia do Estado e desta deduzem todas as demais relações entre este e o indivíduo. Os modernos reconhecem que o Estado, seja natural ou contratual, coloca-se como um meio para obter certas finalidades sociais, em cujo seio o indivíduo é valorado. ${ }^{41}$

Nesse sentido, quando se discute o direito de resistência, não se pode confundi-lo com a resistência que surge do desentendimento entre particulares, que se encontram em uma posição horizontal de direitos. Pois, na verdade, trata-se do indivíduo ou grupo de pessoas, inseridos em uma sociedade constituída, opondo-se e/ou resistindo contra as forças do estado soberano, que ocupa quase sempre status superior, o que torna essa relação indivíduo x estado desigual.

\footnotetext{
${ }^{39}$ SÓFOCLES. Antígone. Tradução de J. B. Mello e Souza. Versão para eBook, 2005. Disponível em <http://direitorio.fgv.br/sites/direitorio.fgv.br/files/antigona.pdf>. Acesso em: 11.07.2017.

${ }^{40}$ BUZANELlO, José Carlos. Direito de Resistência Constitucional. Rio de Janeiro: América Jurídica, 2002, p. 1.

${ }^{41}$ Ibid. p. 1.
} 
Além disso, modernamente, é possível enxergar o direito de resistência com estrita ligação com o direito constitucional, sujeitando-se a uma teoria constitucional, que tem como pressuposto a legitimidade constitucional do poder político. Sendo a resistência encarada como instrumento de controle dos atos públicos, bem como na manutenção do pacto constitucional por parte dos governantes. ${ }^{42}$

A tese do direito de resistência é discutida por inúmeros autores, entre os quais, destaco: Santo Tomás de Aquino, Etienne de La Boétie ${ }^{43}$, Henry David Thoreau, bem como os teóricos contratualistas como John Locke e Thomas Jefferson.

Para Nelson Nery Costa foi a contribuição teórica dos contratualistas que permitiu que a doutrina do direito de resistência alcançasse sua maturação, sendo o ponto comum que perpassava entre eles a concepção de que o Estado surgiu através da criação de um "pacto social como um acordo bilateral de vontades, em que ambas as partes encontravam-se sujeitas a direitos e obrigações" $"$.

O contratualismo é uma corrente doutrinária que discute a origem do poder político através da passagem do estado natural (condição pré-política da qual o homem teria saído) para a sociedade política, estabelecida com regras de convívio social e organização política, a partir de um contrato/acordo celebrado entre a maioria dos indivíduos, o que permite a discussão quanto a legitimidade do poder político. ${ }^{45}$

Dada a notável importância da contribuição das teorias contratualistas para o estudo e compreensão da Teoria do direito de resistência, se faz mister estudar sua abordagem a partir do posicionamento de John Locke com sua famosa teoria liberal. Na esteia do desenvolvimento

\footnotetext{
${ }^{42}$ BUZANELlO, José Carlos. Direito de Resistência. Disponível em http://www.egov.ufsc.br/portal/sites/default/files/anexos/1199-1213-1-PB.pdf. Acesso em: 25.07.2017.

${ }^{43}$ COSTA, Nelson Nery. Teoria e Realidade da Desobediência Civil. 1'a edição. Rio de Janeiro: Forense, 1990, p. 3.

${ }^{44}$ Ibid. p. 3.

45 BOBBIO, Norberto; MATTEUCCI, Nicola; PASQUINO, Gianfranco. Dicionário de Política. Coordenação da Tradução João Ferreira. 11ª .ed. Brasília: Editora UNB, p. 272.
} 
do conceito de direito de resistência também será analisada a importância dos atos políticos de Thomas Jefferson que contribuíram para independência dos Estados Unidos.

\subsection{John Locke}

John Locke (1632-1704), filósofo inglês, foi um dos fundadores da escola empirista e considerado o pai do iluminismo. Aos 58 anos publicou os dois Tratados Sobre o Governo Civil. Locke dissertou principalmente sobre o estado pré-político e a passagem deste para o Estado político, abordando ainda a sua famosa teoria contratualista. No Primeiro Tratado Sobre o Governo Civil, John Locke desconstrói a teoria do direito divino dos reis.

$\mathrm{O}$ autor apresenta argumentos contra o direito divino dos monarcas apresentado por Robert Filmer em seu livro Patriarcha. Filmer argumenta que o poder político fora dado por Deus a um monarca, que seria Adão, que o transmitiria hereditariamente aos seus descendentes. Locke não apenas refutou todas as alegações trazidas pelo autor do Patriarcha, bem como construiu uma tese que defendia que todos os homens são naturalmente livres e iguais.

No Segundo Tratado Sobre o Governo Civil Locke defende que a verdadeira origem do governo é o pacto consciente estabelecido pela comunidade que, em estado de natureza, transfere de forma condicional alguns de seus direitos ao governo. ${ }^{46}$ Conforme historiado, o Segundo Tratado foi concebido como uma justificação ex post facto da Revolução Gloriosa (1668-1669) onde John Locke fundamentou a legitimidade da deposição de Jaime II por Guilherme de Orange e sua esposa Maria, bem

\footnotetext{
${ }^{46}$ MIRANDA, Daniel Moreira. Apresentação: Os dois tratados sobre o governo In: LOCKE, John. Segundo Tratado Sobre o Governo Civil. Tradução: Marsely de Marco Dantas. São Paulo: EDIPRO, 2014, p.10.
} 
como pelo Parlamento com base na doutrina do direito natural de resistência.

A Revolução Gloriosa pôs fim a ameaça de perpetuação da dinastia católica e sua tendência absolutista. Como forma de limitar o poder, Orange e sua esposa ao subirem ao trono assinaram a Bill of Rights, que proibia formalmente aos soberanos a suspensão de leis, criação de impostos, a instituição de jurisdições arbitrárias e manutenção do exército permanente sem o consentimento do Parlamento, além de garantir a liberdade individual dos súditos e seu direito de petição, instituindo na Inglaterra uma monarquia limitada. ${ }^{47}$

Segundo José Carlos Buzanello, John Locke foi o primeiro autor moderno a tratar e defender o ius resistendi com estrita relação com o pacto social limitador da soberania estatal. A teoria lockeana embasada no pacto celebrado entre os indivíduos, que se encontravam em estado de natureza, transfere ao Estado poder de violência, com vistas a assegurar a manutenção da vida pacífica e principalmente dos direitos à vida e à propriedade. $^{48}$ Embasado no direito natural de liberdade, pré-existente ao estado social, este contrato social se mostra como condição e limitação ao poder do estado.

\subsubsection{O Contratualismo Lockeano}

Na construção dos dois Tratados, Locke parte da ideia inicial de que os indivíduos viviam no estado de natureza; sendo este definido como um estado pré-político no qual os homens viviam livremente sob a vigência de leis naturais, racionalmente deduzidas e no qual inexistia uma autoridade estatal.

\footnotetext{
${ }^{47}$ COSTA, Nelson Nery. Ciência Política. $3^{\text {a }}$. edição. Rio de Janeiro: Forense, 2012, p. 217-218.

${ }^{48}$ BUZANELLO, José Carlos. Direito de Resistência Constitucional. Rio de Janeiro: América Jurídica, 2002, p. 55/56.
} 
A fim de superar os riscos existentes no estado de natureza - em razão da ausência de uma autoridade posta que pudesse limitar a liberdade que cada homem possuía, ou punir as transgressões dos direitos naturais do outro - os homens, através de um contrato social, decidem viver sob a égide de um Estado político soberano. Para isso, transferem parte do poder que possuem ao Governo. Consequentemente, a tese da autoridade soberana com poderes advindos de Deus amplamente sustentada pelos antecessores de Locke é afastada.

Além disso, a partir da concepção de um pacto social celebrado de comum acordo pelos homens, possuidores de direitos pré-políticos, é possível delimitar o poder político criado pelas exigências postas na construção do pacto.

No estado de natureza de Locke, os homens viviam na sua condição natural onde se encontravam em total liberdade e igualdade. Não havia qualquer subordinação ou sujeição entre os indivíduos. Todos os homens poderiam agir e dispor livremente de seus bens e pessoas. ${ }^{49}$ Por isso, eram iguais entre si. Ninguém era maior ou melhor que ninguém. Usufruíam da mesma natureza, uma vez que eram governados por uma lei natural que poderia ser racionalmente deduzida por todos, a qual determinava que ninguém deveria prejudicar o outro.

Embora no estado de natureza, delineado por Locke a terra e todas as criaturas fossem comuns a todos, já era possível vislumbrar o direito natural à propriedade privada que surgia a partir do trabalho individual:

O trabalho de seu corpo e o feito por suas mãos pertencem a ele. Àquilo que tira do estado de natureza provê e lega, ele mescla e acrescenta algo que é seu, e, assim, torna tal coisa propriedade sua. Sendo tal coisa removida do estado que a natureza a ela imprimiu, o homem, por meio do seu trabalho, anexou-a a ele, excluindo-a, assim do direito comum dos demais homens. Esse trabalho é propriedade inquestionável do trabalhador, e assim, nenhum outro homem tem direito àquilo que agregou. ${ }^{50}$

\footnotetext{
${ }^{49}$ LOCKE, John. Segundo Tratado Sobre o Governo Civil. Tradução: Marsely de Marco Dantas. São Paulo: EDIPRO, 2014, p. 29.

${ }^{50} \mathrm{Ibid}$. p.44.
} 
Em Locke, a partir do trabalho humano sobre um bem que se encontra em seu estado de natureza, é possível a aquisição deste e acúmulo de propriedade. $\mathrm{O}$ trabalhador que mistura seu trabalho a uma porção de terra adquiri-a, assim como aquele que recolhe os frutos de uma árvore passa a ter direito de propriedade sobre estes.

A partir disso pode-se concluir que as pessoas podem adquirir bens demasiadamente. Os limites a aquisição de bens estão postos na lei natural a qual preceitua que ninguém pode ter mais bens do que possa consumir e lhe cause perecimento.

Deste modo, toda vez que um homem se apropria de uma terra e a deixa improdutiva ou recolhe um fruto que não utiliza e este perece, este homem estará transgredindo a lei natural.

Embora na teoria Lockeana a propriedade privada também seja consequência do trabalho humano sobre os recursos comuns que se encontram dispostos a todos na natureza esta também é possível através da troca, que se torna uma alternativa para que os homens possam acumular riquezas, como o dinheiro ou bens não perecíveis, sem transgredir a lei natural.

$\S 46$. (...) Aquele que colhesse cem alqueires de avelãs ou de maçãs tornava-se proprietário delas; ou seja, elas se tornavam seus bens tão $\log$ o ele as colhesse. Ele tinha apenas que se preocupar em consumi-las antes que estragassem, ou isso significaria que ele fizera uso de uma parte maior da que podia, o que lhe valeria a acusação de haver roubado as demais pessoas. E acumular mais do que podia usar ou consumir era mesmo uma tolice, um verdadeiro ato de desonestidade. Uma opção seria distribuir uma parte da colheita a outras pessoas, o que significaria um bom uso. Feito isso, se os produtos perecessem, já não seriam mais seus, pois estariam nas mãos das pessoas que o aceitaram e não consumira. E se ele também trocasse ameixas que teriam perecido em uma semana, por nozes que durariam um ano inteiro, não haveria problema, ou seja, ele não desperdiçaria o suprimento comum, nem destruiria qualquer parte da porção dos bens que pertencessem aos outros, contanto, é claro, que nada perecesse inutilmente em suas mãos. Se a troca fosse de nozes por uma barra metálica, cuja a cor fosse de seu agrado, ou de ovelhas por conchas, ou de lã por uma pedra brilhante ou um diamante, e os mantivesse consigo durante toda a vida, não estaria lesando o direito dos outros. Ele poderia acumular tais bens duráveis por tanto tempo quando quisesse, haja vista que o limite excedente de sua legitima 
propriedade não estavam no tamanho de suas posses, mas na deterioração inútil de qualquer coisa em seu poder.

$\S 47$. Assim sendo, o uso do dinheiro foi estabelecido como algo que durasse e que os homens pudessem aguardar sem estragar, e que, por consenso comum, empregassem na troca de recursos uteis para sua vida, mesmo que fossem perecíveis.

A partir da leitura da obra de Locke, é possível perceber que, embora o conteúdo da lei natural tanto falada não seja muito claro, para o autor, pela racionalização e compreensão da lei natural esta ditava a propriedade como direito fundamental ao homem. $\mathrm{O}$ direito à propriedade possuía um efeito amplo que se desdobrava em direito à vida, à liberdade e à propriedade de bens, caracterizando direitos individuais e naturais, préexistentes ao estado social, e que sendo assim, deveriam ser respeitados após o pacto.

A Lei Natural exposta por Locke, que dá a liberdade que os homens desfrutavam no estado natural, não era um estado de licença. Os homens possuíam liberdade para dispor de seus bens ou de si mesmos. No entanto, a própria destruição ou a destruição de criaturas que lhes pertenciam só eram permitidas por algum motivo mais nobre que a conservação. ${ }^{51} \mathrm{~A}$ mesma lei natural que obrigava a todos a não prejudicar o outro também lhes permitia a autopreservação e a punição. Como pode se depreender da leitura do seguinte trecho:

E que todos os homens sejam impedidos de violar os direitos ou de causar qualquer mal ao próximo; e que o direito natural seja respeitado, garantindo a paz e a preservação de toda a humanidade; a exceção do direito natural fica, dessa forma, na mão de cada homem, permitindo que os ofensores da lei sejam punidos de acordo com suas violações. (...) E se qualquer um, no estado de natureza, pudesse punir outra pessoa por um mal causado, todos poderiam fazer o mesmo; em um estado de perfeita igualdade, não havendo superioridade nem jurisdição de uma pessoa sobre a outra, o que alguém puder fazer em busca de justiça também poderá ser feito por todos. ${ }^{52}$

Embora no estado de natureza lockeano os homens possuam liberdade e possam viver felizes e usufruir dos direitos naturais pré-

\footnotetext{
${ }^{51}$ Ibid. p. 30.

${ }^{52}$ Ibid. p. 31.
} 
existentes, o gozo desses direitos é ameaçado, uma vez que, sendo todos iguais, se um homem resolvesse não respeitar o direito do outro não existia uma autoridade civil com poder de fiscalizar os atos dos indivíduos, nem mesmo de puni-los.

Em vista disso, os homens unem-se e sujeitam-se ao estado social em prol da preservação de seus direitos. "A finalidade maior e principal de os homes se unirem em comunidades civis, de acordo com o julgo de um governo, é a preservação de suas propriedades.

No estado de natureza, há muitas carências". ${ }^{53}$ Locke reconhece que o estado de natureza careceria de uma lei conhecida e aceita pelo consentimento da maioria, capaz de padronizar e regular as controvérsias; de um juiz conhecido, imparcial e capaz de decidir com base na lei estabelecida; e ainda, um poder instituído com força de apoiar a decisão do juiz garantindo com que ela fosse cumprida.

Uma vez que no estado de natureza não existia uma lei posta e por todos conhecida, nem mesmo uma autoridade civil para fiscalizar os atos de cada indivíduo, sendo de cada homem esse exercício, todos poderiam atuar como seus próprios juízes, levados pela paixão, ódio ou sentimento de vingança.

É previsível que poderiam ser cometidos exageros nas punições que poderiam culminar em um estado de violência, desordem e guerra. Sendo assim, segundo Locke, viu-se no governo civil o remédio para superar essas inconveniências. ${ }^{54}$ Nesse sentido, conforme salientado por Nelson Nery Costa, o pressuposto inicial da teoria lockeana se constituiu no princípio de que o indivíduo é proprietário de si mesmo, caracterizando um direito do homem de ser livre e igual diante dos outros. ${ }^{55}$

A liberdade do indivíduo era de suma importância no estado de natureza, mas não era ilimitada. Uma vez que o poder executivo pertencia a todos os indivíduos no estado de natureza, se alguém ofendesse os limites

\footnotetext{
${ }^{53}$ Ibid. p. 101.

${ }^{54}$ Ibid. p. 34.

${ }^{55}$ COSTA, Nelson Nery. Ciência Política. $3^{\mathrm{a}}$. edição. Rio de Janeiro: Forense, 2012, p. 225.
} 
da lei natural, surgia para todos os outros homens o direito de puni-lo. Isso causava uma intranquilidade geral, sendo a constituição do pacto entre os indivíduos a única saída encontrada para resolução desse impasse. ${ }^{56}$ Deste modo, a fim de evitar esses inconvenientes, os homens através da união de seus consentimentos, de forma livre, instituíram um governo.

Nos últimos capítulos do Segundo Tratado Sobre o Governo Civil Locke analisa quatro formas de degeneração do Governo: a conquista, a usurpação, a tirania e a dissolução do Governo. A conquista não pode ser considerada uma forma de origem de governo, uma vez que a força das armas não é capaz de substituir o consentimento do povo, sem o qual é impossível erguer um novo Estado. ${ }^{57}$ A usurpação é uma espécie de conquista doméstica. Ocorre quando alguém se apodera do poder que, por direito, pertence a outra pessoa. Se o usurpador já obtivesse o poder, e o estendesse para além do que tem direito, tratar-se-ia de um ato de tirania. ${ }^{58}$ A tirania é o exercício do poder para além do direito. O que significa usar o poder que se tem legitimamente nas mãos, mas não para o bem a que se destina, mas em benefício próprio. Caracterizando abuso de poder. ${ }^{59}$

\subsubsection{Resistência em Locke}

A partir da leitura da obra de Locke é possível verificar-se que o autor defende o exercício do ius resistendi pelo povo toda vez que o soberano os submetesse a situações que excedessem os poderes previstos no acordo pactuado, como se verá a seguir.

Segundo Locke, quando ocorria conquista territorial decorrente de uma guerra justa, só era permitido o exercício do poder despótico sobre aqueles que lhe levantaram as armas. Aos que permaneceram neutros, não

\footnotetext{
${ }^{56}$ COSTA, Nelson Nery. Teoria e Realidade da Desobediência Civil. 1 $1^{\text {a }}$. edição. Rio de Janeiro: Forense, 1990, p. 9-10.

${ }^{57}$ LOCKE, John. Segundo Tratado Sobre o Governo Civil. Tradução: Marsely de Marco Dantas. São Paulo: EDIPRO, 2014, p.137.

${ }_{58}$ Ibid, p. 149.

${ }^{59}$ Ibid. p. 151.
} 
estariam obrigados a obedecer ao vencedor, que caso atentasse contra a propriedade (em sentido lato - vida, liberdade, propriedade) dos conquistados, seria posto em estado de guerra. ${ }^{60}$

$\mathrm{Na}$ usurpação ocorreria apenas a mudança da pessoa governante, mantendo-se as instituições. No entanto, nenhum direito teria o usurpador de ser obedecido, pois, careceria do livre consentimento dos indivíduos para ter a autoridade confirmada. ${ }^{61}$

Na tirania, a utilização das prerrogativas governamentais, de forma arbitrária, retirava do governado o dever de obediência. ${ }^{62}$ Quando a pessoa do príncipe fosse considerada sagrada, o rei só poderia ser oposto quando fizesse uso injusto da força; caso contrário, pela doutrina da legitimidade da resistência a todo exercício ilegal do poder, primeiramente deveriam tentar reparar os danos causados pelos meios legais, somente no caso de ser a tentativa frustrada, se liberaria o uso da força pelos opositores. ${ }^{63}$

Ao abordar a dissolução do governo, Locke, inicialmente, distingue dissolução da sociedade e dissolução do governo. A dissolução da sociedade ocorre quando uma força estrangeira vem a conquistar. Com isso, cada homem, da sociedade conquistada, retorna ao estado anterior ao pacto, com liberdade para buscar sua própria segurança. ${ }^{64} \mathrm{~A}$ dissolução do governo ocorre com forças vindas de dentro. ${ }^{65}$ Por culpa do Legislativo ou do Executivo.

Como culpa do Legislativo, Locke elenca a quebra de confiança com a troca do Legislativo de forma arbitrária. ${ }^{66}$ Como culpa do Executivo, Locke enumera as seguintes situações: quando o único governante, ou príncipe, substitui as leis emanadas do poder legislativo, e que representam a vontade geral, de forma arbitrária; quando o príncipe impede a reunião da

\footnotetext{
${ }^{60}$ COSTA, Nelson Nery. Ciência Política. $3^{\mathrm{a}}$. edição. Rio de Janeiro: Forense, 2012, p. 234.

${ }^{61}$ Ibid. p. 234-235.

62 Ibid. p. 235.

${ }^{63}$ Ibid. p. 235.

${ }^{64}$ LOCKE, John. Segundo Tratado Sobre o Governo Civil. Tradução: Marsely de Marco Dantas. São Paulo: EDIPRO, 2014, p. 157.

65 Ibid. p. 158.

${ }^{66}$ Ibid. p. 158.
} 
assembleia legislativa, em época já determinada, ou de agir com liberdade; quando, arbitrariamente, o príncipe altera as regras eleitorais; quando o povo é entregue ao julgo de um poder estrangeiro; e, quando aquele que exerce o poder executivo negligencia e abandona seu cargo, impedindo que as leis possam ser executadas. ${ }^{67}$

Estas situações, por tratarem-se de problemas na esfera institucional, também facultam a desobediência formalmente. Já o direito de resistência dos homens em sociedade civil, de se revoltar e de retomar suas prerrogativas, ocorreria:

Sempre que os legisladores planejam tomar e destruir a propriedade do povo, ou reduzi-lo à escravidão por um poder arbitrário, eles ficam em estado de guerra com o povo, que por causa disso fica isento de qualquer obediência, sendo deixado à proteção que Deus concede a todos os homens contra a opressão e a violência. Consideremos, sempre que o legislativo transgride essa regra fundamental da sociedade e, ou por ambição, medo, insensatez ou corrupção, tenta dominar a si mesmo, ou pôr nas mãos de qualquer outro um poder absoluto sobre as vidas, liberdades e propriedades do povo; (...) sempre que por essa quebra de confiança, o legislativo confisca o poder que o povo passou às suas mãos com propósitos bem contrários, e o devolve ao povo, que tem direito a retomar sua liberdade inata; e sempre que, pelo estabelecimento de um novo legislativo (da forma que melhor lhe aprouver), o povo garante sua própria tranquilidade e segurança; está aí a razão pela qual os homens vivem em sociedade. $\mathrm{O}$ que digo aqui em relação ao legislativo em geral é igualmente verdadeiro em relação ao executor supremo, que, por ser detentor de uma dupla confiança, tanto como participante do legislativo, quanto da suprema execução da lei, age contra ambos, quando começa a impor sua própria vontade arbitrária como a lei da sociedade. ${ }^{68}$

Ante o exposto, a resistência representa para o autor inglês o instrumento que os cidadãos deveriam utilizar para combater o abuso dos governantes, sempre que estes extrapolassem os limites de suas prerrogativas.

A resistência, segundo o autor, necessitaria de três requisitos para que fosse legítima: que o arbítrio estatal expusesse os indivíduos a efetivos maus-tratos; que fosse utilizado por qualquer motivo, mas após reiteradas

\footnotetext{
${ }^{67}$ Ibid. p. 158-159.

${ }^{68}$ Ibid. p. 162.
} 
infrações; e que os resistentes não fizessem uso da força, sob o risco de serem considerados rebeldes, o que suscitaria a volta ao estado de guerra. ${ }^{69}$

No entanto, o medo de pôr em risco a paz, seja pela eclosão de guerras civis, ou de outras perturbações sociais, não deveria impedir que o povo resistisse:

\begin{abstract}
Entretanto, aqueles que dizem que "isso é uma base para a rebelião", na verdade, querem dizer que pode provocar uma guerra civil, ou uma dor de barriga, dizer ao povo que ele está livre da obediência quando tentativas ilegais forem feitas contra suas liberdades ou propriedades; e que pode se opor à violência ilegal dos que eram seus magistrados, quando esses invadirem suas propriedades, traindo a confiança que lhes foi depositada; e que, portanto, essa doutrina não deve ser permitida, pois pode destruir a paz mundial. Pode-se até dizer, da mesma forma, que homens honestos não têm o direito de se opor a ladrões e piratas, porque isso pode causar desordem e derramamento de sangue. Se acontece algum prejuízo nesses casos, não se deve responsabilizar aquele que defende os próprios direitos, e sim aquele que viola os direitos do seu vizinho. Se o homem honesto e inocente deve entregar tudo que possui, sem alarde e pela paz, para o opressor violento, pergunto: que tipo de paz haverá em um mundo, mantido em benefício dos ladrões e dos opressores, em que apenas a violência e a pilhagem prevalecem $?^{70}$
\end{abstract}

Por entender que ao se submeter ao pacto o povo não abdica do poder supremo, apenas delega esse aos governantes, que perdem a sua legitimidade quando desrespeitam as leis que obrigam a todos, Locke defendeu a possibilidade de resistência dos indivíduos quando o Executivo ou o Legislativo operam a dissolução do governo, nascendo para o povo o direito de retomar sua liberdade natural e de instituir um novo Legislativo. Vale ressaltar que neste caso, para o autor, o novo Legislativo não deveria sofrer mudanças radicais.

\footnotetext{
${ }^{69}$ MARTINS, Carlos Estevan e MONTEIRO, João Paulo. Locke: Vida e Obras. In: LOCKE, John. Os Pensadores: Locke, op. cit., pp. XV/XVI Apud COSTA, Nelson Nery. Ciência Política. $3^{\mathrm{a}}$. edição. Rio de Janeiro: Forense, 2012, p. 236-237.

${ }^{70}$ LOCKE, John. Segundo Tratado Sobre o Governo Civil. Tradução: Marsely de Marco Dantas. São Paulo: EDIPRO, 2014, p. 165-166.
} 
Locke confiava que a sociedade não se distanciaria das formas antigas e de que as mudanças estariam calçadas na necessidade de um novo processo político e no espírito conservador dos homens. ${ }^{71}$

Em conclusão, o poder político que cada homem abdica em favor do Governo Civil na instituição do pacto, permanece com a comunidade, para que possa ser retomado e exercido em casos de arbitrariedades, e a ordem seja reestabelecida:

(...) o poder que cada indivíduo deu à sociedade, com sua associação, nunca pode ser devolvido a ele enquanto a sociedade existir; entretanto, esse poder sempre permanecerá na comunidade, pois sem ele não existe qualquer comunidade, nem mesmo uma comunidade civil, o que é contrário ao acordo inicial. $^{72}$

\subsection{O Dever de Resistência em Thomas Jefferson}

Thomas Jefferson (1743-1826), assim como Locke, defendia a teoria contratualista, logo, via o estado político como decorrente de um pacto social. Foi presidente dos Estados Unidos da América - exercendo dois mandatos (1801-1809) - ficou muito conhecido pelos seus atos políticos, os quais foram de suma importância para a Independência dos EUA, sendo sua obra mais famosa a célebre Declaração de Independência dos Estados Unidos. $^{73}$

Segundo Nelson Nery Costa, para Thomas Jefferson, a liberdade era vista como o princípio basilar da política, uma vez que dependia da vontade individual, mas não podia atingir os direitos alheios. ${ }^{74}$

Assim, representava a exteriorização dos direitos naturais, que deviam nortear as legislações, delineando os limites do poder dos governos.

\footnotetext{
${ }^{71}$ COSTA, Nelson Nery. Ciência Política. $3^{\text {a }}$. edição. Rio de Janeiro: Forense, 2012, p.237.

${ }^{72}$ LOCKE, John. Segundo Tratado Sobre o Governo Civil. Tradução: Marsely de Marco Dantas. São Paulo: EDIPRO, 2014, p. 175.

${ }_{73}^{73}$ COSTA, Nelson Nery. Ciência Política. $3^{\text {a }}$. edição. Rio de Janeiro: Forense, 2012, p. 318.

${ }^{74}$ Ibid. p. 318.
} 
Para Jefferson, o direito à vida, à liberdade e à busca da felicidade, constituía direitos fundamentais do homem, por isso não eram transmitidos à sociedade política no momento da constituição do pacto social.

Assim, esses direitos, bem como os que não eram primordiais para que o governo desempenhasse suas atividades, e, ainda, os que poderiam ser utilizados pelos homens como meio de defesa contra as arbitrariedades do poder, permaneciam em poder do indivíduo, na esfera privada de cada cidadão, preservando sua autonomia privada. ${ }^{75}$

Uma vez que considerava que todo homem possuía o direito natural ao autogoverno - o que lhes atribuía autonomia civil e política - a fonte da autoridade da sociedade política deriva do povo, da soma das vontades individuais. Tal concepção acerca do poder significava que, ainda que inserido dentro de uma sociedade política organizada, com poder constituído, o indivíduo não perdia seu direito natural de liberdade, que o acompanhava.

Jefferson defendia que a sociedade política fora criada pelos homens a fim de preservar os seus direitos naturais, inalienáveis, anteriores ao estado, e que por conta disso deveriam ser respeitados pelas autoridades políticas. Deste modo, se o governo atuasse de modo contrário ao pactuado no contrato, os indivíduos eram automaticamente liberados de obedecerem às leis positivas, e nasceria para eles muito mais que o direito, mas o dever de resistência.

Consideramos estas verdades como evidentes por si mesmas, que todos os homens são criados iguais, dotados pelo Criador de certos direitos inalienáveis, que entre estes estão a vida, a liberdade e a procura da felicidade. Que a fim de assegurar esses direitos, governos são instituídos entre os homens, derivando seus justos poderes do consentimento dos governados; que, sempre que qualquer forma de governo se torne destrutiva de tais fins, cabe ao povo o direito de alterá-la ou aboli-la e instituir novo governo, baseando-o em tais princípios e organizando-lhe os poderes pela forma que lhe pareça mais conveniente para realizar-lhe a segurança e a felicidade (...) Mas quando uma longa série de abusos e usurpações, perseguindo invariavelmente o mesmo objecto, indica o desígnio de reduzi-los ao despotismo absoluto,

\footnotetext{
${ }^{75}$ Ibid. p. 319.
} 
assistem-lhes o direito, bem como o dever, de abolir tais governos e instituir novos Guardiães para sua futura segurança $(. .)^{76}$

Nelson Nery também menciona em sua obra que Thomas Jefferson via o ato de opor-se ao governo como um poder-dever, uma vez que os cidadãos não poderiam agir passivamente diante de violações aos direitos naturais ${ }^{77}$. Assim, considerava o direito de resistência como um instrumento adequado pelo qual os indivíduos poderiam se proteger das arbitrariedades do governo. ${ }^{78}$

Segundo, ainda, o autor, as obras de Locke contribuíram e influenciaram os feitos de Thomas Jefferson; no entanto, Jefferson foi além, debruçando-se sobre o tema do contrato social, liberdades e deveres do estado político e do cidadão de forma mais aprofundada que o inglês. ${ }^{79}$ No Segundo Tratado Sobre o Governo Civil, Locke tratou que após a instituição do pacto, com a constituição da sociedade civil, os direitos naturais do homem passam para a sociedade retornando a ele somente em casos de arbitrariedades e injustiças. Uma vez que a transferência do poder se deu sob condição do cumprimento de certas obrigações por parte do governante, se estas não são cumpridas, o povo retoma o poder.

Contudo, na Declaração de Independência dos Estados Unidos, fica clara a intenção de Jefferson, de que, mesmo após a constituição da sociedade civil, os direitos naturais devem permanecer como direitos individuais, em poderio do cidadão, à espreita de ser exercido autonomamente.

Além dessas diferenças, o autor ainda aborda a distinção do termo "propriedade" para ambos os autores. ${ }^{80}$ Para Locke o direito de propriedade é um direito natural, com um amplo significado; que englobava a vida,

${ }^{76}$ JEFFERSON, Thomas. A Declaração da Independência dos Estados Unidos da América, disponível

em $<$ http://www.uel.br/pessoal/jneto/gradua/historia/recdida/declaraindepeEUAHISJNeto.pdf $>$ acessa do em: 02/07/17.

${ }^{77}$ COSTA, Nelson Nery. Teoria e Realidade da Desobediência Civil. 1 ${ }^{\text {a }}$. edição. Rio de Janeiro: Forense, 1990. p. 19.

Ibid. p. 19.

${ }^{79}$ Ibid. p. 19

${ }^{80}$ COSTA, Nelson Nery. Ciência Política. $3^{\text {a }}$. edição. Rio de Janeiro: Forense, 2012, p. 320. 
liberdade e os bens. Já para Jefferson, a partir do exposto pelo autor, referia-se a propriedade de bens, e era produto da sociedade, e não anterior à esta, como são os direitos naturais. ${ }^{81}$

$\mathrm{O}$ processo de independência dos Estados Unidos foi influenciado pelos ideais iluministas que difundiram o direito à liberdade e a resistência a um governo autoritário. Embora no início da colonização americana a intervenção inglesa sobre suas 13 colônias na América do Norte tenha sido moderada, o controle, sobretudo fiscal foi se intensificando. Ainda, a guerra dos sete anos (1756-1763) da Inglaterra contra a França acelerou a política fiscal que estava sendo introduzida pouco a pouco.

A Lei do Selo e a Questão do Chá determinaram os momentos culminantes dos conflitos, de modo que, insatisfeitos com os abusos da metrópole o Segundo Congresso, determinou a separação em relação à Inglaterra. Em 4 de julho de 1776, foi publicada a declaração de independência dos Estados Unidos, redigida por Thomas Jefferson. ${ }^{82}$

\subsection{Conclusão do Capítulo}

Conforme exposto, o tema do direito de resistência é objeto das mais variadas construções teóricas. Embora seja difícil precisar a primeira menção do ius resistendi na história, acredita-se que antes de Cristo esta forma de defesa já havia sido prevista no Código de Hamurabi e na Grécia antiga com Antígona. Desde então, o instituto do direito de resistência temse aprimorado. A teoria do direito de resistência desenvolvida por John Locke e Thomas Jefferson, sem sombra de dúvidas, proporcionaram um grande avanço na história da sociedade. A partir das quais, o ius resistendi foi integrado como instrumento a serviço do povo, adequado a combater o arbítrio estatal.

\footnotetext{
${ }^{81}$ Ibid. p. 320.

${ }^{82}$ COSTA, Nelson Nery. Ciência Política. $3^{\text {a }}$. edição. Rio de Janeiro: Forense, 2012, p. $317 / 318$.
} 
A obra, o Segundo Tratado Sobre o Governo Civil foi criada sob o pretexto de justificar a Revolução Gloriosa, bem como legitimar a deposição de Jaime II por Guilherme de Orange e sua esposa Maria, e pelo Parlamento com base na doutrina do direito natural de resistência. Em que pese isto, hoje é considerada uma das obras mais importantes sobre o modelo liberal, uma vez que o pacto social lockeano possui o consentimento que legitima o estado político posto. No entanto, o mesmo consentimento que fundamenta a nova ordem é legitimo para fazer valer a garantia dos direitos naturais que pretende ter resguardado, de modo que, se violados pelo Estado nasce para o indivíduo o direito de resistência de resguarda-los.

Thomas Jefferson construiu sua doutrina de direito de resistência inspirado no Segundo Tratado Sobre o Governo Civil de John Locke. A partir da leitura da Declaração de Independência dos Estados Unidos notase que para Jefferson era um contratualistas e defendia que os governantes estão vinculados a assegurar e respeitar os direitos naturais, como a vida, a liberdade e a busca da felicidade. Ainda, para Thomas Jefferson, esses direitos não se transmitem ao estado político no momento do pacto, permanecem com os indivíduos e servem como limitação da atuação estatal. 


\section{SOBRE A DESOBEDIÊNCIA CIVIL}

A partir do estudado, constata-se que o desenvolvimento e utilização do direito de resistência estava condicionado a união de vontades da maioria. Em razão disso, as minorias encontravam dificuldades para exercerem suas defesas em face dos abusos estatais. Grupos minoritários não tinham legitimidade para utilizarem-se do instituto do direito de resistência a fim de requererem que suas pautas fossem ouvidas e atendidas em razão das teorias deste direito estarem consolidadas na defesa dos direitos do povo.

Ao lado do desenvolvimento teórico acerca do tema, o modo de exercício do direito de resistência foi ampliado a partir da ideia de desobediência civil introduzida por Henry D. Thoreau. Tal exercício do direito de resistência deixou de exigir a participação da vontade da maioria, permitindo o exercício do direito de resistir aos grupos minoritários e até mesmo ao indivíduo. Em razão disso, a desobediência civil pode receber o status de direito de cidadania, como se demonstrará no próximo capítulo.

\subsection{Apontamentos Gerais Sobre a Desobediência Civil}

Conforme já mencionado, a desobediência civil é uma das formas de exercício do direito de resistência; ela recebe este nome justamente para ressaltar o ato de reivindicação a seguimentos específicos da sociedade, mantendo-se a fidelidade geral ao Estado ${ }^{83}$. Assim pode opor-se à uma lei, uma norma, um comportamento da ordem jurídica ou política o qual se deseja reformar ou revogar, com a manutenção de todo o resto do ordenamento.

\footnotetext{
${ }^{83}$ Ibid. p. 44.
} 
Para o doutrinador José J. Gomes Canotilho, sob o ponto de vista jurídico-constitucional, a desobediência civil define-se como o direito de qualquer cidadão de infringir uma norma de proibição; individual ou coletivamente, de forma pública e sem violência ${ }^{84}$. Fundamentando-se em imperativos éticos-políticos, com o escopo de protestar e proporcionar a adequada notoriedade ao ato, em razão de uma grave injustiça. ${ }^{85}$

Nas palavras de Hanna Arendt a desobediência Civil surge:

(...)quando um número significativo de cidadãos se convence de que, ou os canais normais para mudanças já não funcionam, e que as queixas não serão ouvidas nem terão qualquer efeito, ou então, pelo contrário, o governo está em vias de efetuar mudanças e se envolve e persiste em modos de agir cuja legalidade e constitucionalidade estão expostas a grave dúvidas. ${ }^{86}$

É comum que algumas pessoas encontrem semelhanças entre o instituto da objeção de consciência e da desobediência civil, no entanto, estes não se confundem. A objeção de consciência - que também é um dos modos de exercício do ius resistendi - pode ser definida como a recusa ao cumprimento dos deveres legais, por serem incompatíveis com suas convicções morais e/ou pessoais ${ }^{87}$; já a desobediência civil busca demonstrar a injustiça da lei. O desobediente, através da publicidade do seu ato de transgressão, deseja ver uma norma que considera injusta alterada. ${ }^{88}$ Já o objetor de consciência deseja tão somente ter preservado seu direito de não cumprir um dever legal.

Nesse mesmo sentido, John Rawls define a desobediência civil como um ato "público, não violento, consciente e não obstante um ato político, contrário à lei, geralmente praticado com o objetivo de provocar uma

\footnotetext{
${ }^{84}$ CANOTILHO, José Joaquim Gomes. Direito constitucional e Teoria da Constituição. $6^{\mathrm{a}}$ Edição. Coimbra: Almedina, 1993, p. 455.

${ }^{85}$ CANOTILHO, José Joaquim Gomes. Direito constitucional e Teoria da Constituição. $6^{\mathrm{a}}$ Edição. Coimbra: Almedina, 1993, p. 455.

${ }^{86}$ ARENDT, Hannah. Crises da República. Tradução de José Volkmann. $3^{\text {a }}$ ed. São Paulo: Perspectiva, 2015. p. 68.

${ }^{87}$ MARIA, Garcia. Op. cit. p. 292.

${ }^{88}$ LAFER, Celso. A Reconstrução dos Direitos Humanos: um diálogo com o pensamento de Hannah Arendt. São Paulo: Companhia das Letras,1991. p. 200.
} 
mudança na lei e nas políticas do governo." ${ }^{, 89}$ Para o autor, ao agir dessa forma, pretende o desobediente tocar no senso de justiça da maioria da comunidade para que percebam que, com as injustiças perpetradas, os princípios da cooperação entre os homens livres e iguais estão sendo desrespeitados.

John Rawls ainda esclarece que, o ato de desobediência civil não exige que a lei contra a qual se protesta seja violada; aludindo que a desobediência civil pode ser exercida diretamente ou indiretamente. A desobediência civil direta, seria o ato de transgredir a lei considerada injusta; já a desobediência civil indireta, seria o ato de transgredir uma lei, que não aquela que considera injusta, com o fito de demonstrar sua desaprovação a ela e apresentar seus argumentos. ${ }^{90}$

John Rawls, mais uma vez, destaca a importância de se observar que a desobediência civil é um ato político, uma vez que se dirige a maioria que detém o poder político, bem como por ser um ato pautado em princípios políticos $^{91}$.

Os desobedientes invocam a concepção que comumente é compartilhada como ideais de justiça e que estruturam a ordem política. Recorrem, a condição de que em um regime político razoavelmente democrático, os cidadãos perpetuem o sentimento público de justiça na regulação de suas atividades políticas e na interpretação da constituição. Pela prática da desobediência civil, os desobedientes obrigam que a maioria reflita se seus atos são ou não justos, em vista do senso público de justiça. ${ }^{92}$

O núcleo conceitual da desobediência civil apresenta características específicas que permite distingui-la de outros comportamentos do cidadão frente ao Estado, sendo as principais: ${ }^{93}$

\footnotetext{
${ }^{89}$ BEDAU, H. A. “On Civil Disobedience”, Journal of Philosophy, vol. 58 (1961), pp. 653-661 Apud. RAWLS, John. Uma Teoria da Justiça. Tradução: Almiro Piseta e Lenita M.R. Esteves. São Paulo: Martins Fontes, 2000. p. 404.

${ }^{90}$ Ibid. p. 404.

${ }^{91}$ Ibid. p. 405.

92 Ibid. p. 405.

${ }^{93}$ COSTA, Nelson Nery. Teoria e Realidade da Desobediência Civil. $1^{\text {a }}$. edição. Rio de Janeiro: Forense, 1990. p. 44.
} 
i. Número de participantes - Pode ser exercida individual ou coletivamente.

ii. Caráter público - A desobediência é um ato público e aberto. Os desobedientes confiam suas intenções ao público, e expõem seus motivos na expectativa de terem julgamentos favoráveis e conseguirem apoio de parcela maior da população; ${ }^{94}$

iii. Utilização como último recurso - utilizada após esgotadas todas as possibilidades de mudanças por meio de negociações ou outro instrumento jurídico;

iv. Não violento - é entendimento unânime entre os autores de que a violência não pode ser utilizada sob pena de se descaracterizar o adjetivo "civil" do movimento;

v. Sujeição às sanções - Os desobedientes não resistem a aplicação das sanções legais previstas.

Superadas estas considerações iniciais acerca da desobediência civil como exercício do direito de resistência, imperioso se faz, agora, analisar esta espécie do ius resistendi a partir da contribuição teórica de Henry David Thoreau, propulsor do debate da prática individual da desobediência civil; bem como dos feitos de Martin Luther King Jr., que é notadamente conhecido como Líder do movimento pelos direitos civis dos negros nos EUA a partir do uso coletivo da desobediência civil e de Mahatma Gandhi o qual, a parti do movimento de resistência sem violência lutou pelos direitos civis e políticos dos indianos.

\subsection{Henry David Thoreau: O Exercício individual da Desobediência Civil}

Thoreau foi o responsável pelo surgimento do termo "Desobediência Civil", título dado ao seu discurso The right and duties of the individual in relation to government, elaborado em 1848 para descrever suas

\footnotetext{
${ }^{94}$ Ibid. p. 46.
} 
experiências e reflexões, e expor os motivos que lhe levaram a recusar o pagamento de tributos estaduais criados pelo governo norte americano para financiar a guerra contra o México - que considerava injusta - bem como manter a escravidão. Por tal feito foi preso em 1846 sendo liberado somente após o pagamento do seu imposto, contra sua vontade, por alguém até hoje desconhecido pelos biógrafos. ${ }^{95}$

H. D. Thoreau aceitou a pena imposta a ele por desobedecer a uma lei, não resistiu à prisão, pelo contrário manifestou considerar um mérito ter sido preso já que, segundo o autor, frente a um governo injusto a prisão é o lugar destinado aos homens justos.

Em um governo que aprisiona qualquer um injustamente, o verdadeiro lugar de um homem justo também é a prisão. Atualmente, o lugar apropriado - o único lugar que Massachusetts oferece a seus espíritos mais livres e menos desesperados - são suas prisões, onde serão colocados e excluídos do Estado por seu próprio ato, assim como já foram deixados de fora por seus princípios. ${ }^{96}$

Em sua obra, Thoreau defende o direito do cidadão se manifestar de acordo com sua consciência, ainda que para isso seja necessário desobedecer a lei - e isso deveria acontecer toda vez que o indivíduo considerasse a lei injusta - então seu célebre texto Desobediência civil mostra os argumentos favoráveis ao seu exercício e como deve ser exercido esse direito $^{97}$.

Thoreau inicia seu discurso com a frase, tradicionalmente atribuída a Thomas Jefferson "o melhor governo é aquele que governa menos", em seguida expõe a sua opinião "o melhor governo é aquele que não governa", ao contrário do que pode parecer, não almeja o fim do governo, mas um governo melhor. Ele argumenta que a governança é exercida pela vontade da maioria, não porque a maioria é mais justa, mas porque é fisicamente mais forte, por conta disso o governo por vezes pode ser injusto. Defende

\footnotetext{
${ }^{95}$ THOREAU, Henry David. A desobediência civil. Tradução: Daniel Moreira Miranda. São Paulo: EDIPRO, 2016. p. 19-20.

${ }^{96}$ THOREAU, Henry David. A desobediência civil. Tradução: Daniel Moreira Miranda. São Paulo: EDIPRO, 2016. p. 60.

${ }^{97}$ Ibid. p. 19-20.
} 
que todos têm a obrigação de seguir sua própria consciência ainda que seja contrária a vontade da maioria - ao governo, a lei - "a única obrigação que tenho o direito de aceitar é fazer a qualquer momento o que acredito ser correto" 98 .

Há um trecho de sua obra em que fica claro que seu objetivo principal não é incentivar uma manifestação revolucionária, não quer pôr o governo a baixo, sua preocupação maior é sua consciência individual, não agir contrariamente a seus princípios e ideais:

Não é dever de qualquer homem, por uma questão lógica, dedicar-se à erradicação de qualquer erro, nem mesmo do maior de todos; ele ainda pode corretamente estar engajado em outras preocupações, mas é seu dever, ao menos, lavar as mãos e caso não pense mais nisso - não oferecer seu apoio prático. ${ }^{99}$

Sobre as leis injustas Thoreau questiona, se "devemos nos contentar em obedecê-las, ou será que devemos nos esforçar para alterá-las, respeitando-as até que tenhamos obtido sucesso ou, então, devemos transgredi-las de uma vez por todas? "100, e defende que o indivíduo que não concorda com determinadas leis por considera-las injustas não deveria esperar o apoio da maioria para se insurgir contra o governo, devendo agir de pronto, como manda sua consciência, defendendo assim o exercício do direito de resistência pela minoria e individualmente. Referindo-se ao imposto que financiava a escravidão, o qual negou-se a pagar, ele explica como resistir de forma pacífica:

(...)aqueles que se intitulam abolicionistas devem retirar seu apoio ao governo de Massachusetts imediatamente e de forma efetiva, tanto o pessoal quanto o material, e não esperar até que eles consigam construir uma maioria de um que lhes dê o direito de prevalecer (...)

\footnotetext{
98 Ibid. p. 50.

${ }^{99}$ Ibid. p. 56.

${ }^{100}$ Ibid. p. 57.
} 
Eu sei bem que se mil, cem ou dez homens que conheço - se apenas dez homens honestos - sim, se um homem honesto no presente estado de Massachusetts deixasse de possuir escravos e, verdadeiramente, se retirasse dessa sociedade e fosse trancado na cadeia municipal, isso, de fato, já seria a abolição da escravidão na América. Pois mesmo que comece de forma muito pequena, o que se faz bem uma vez, está feito para sempre. ${ }^{101}$

A obra de Thoreau influenciou Gandhi, no entanto, conforme bem observado por Celso Lafer, a postura de Gandhi, diferenciou-se da de Thoreau. Para o indiano, a prática da não violência (da qual se utilizou no processo de independência da Índia) sendo aplicada em ação coletiva assume as características de um direito individual, que conquistará o desejado com a união de um grande número de pessoas, agindo em conjunto.

Neste sentido, a desobediência civil ganha afinidade com os direitos individuais que só podem ser exercidos coletivamente, como o direito de greve; e ainda, postulou como nota específica uma ética de grupo. Gandhi não diferenciou o que é lícito ao indivíduo e o que é lícito ao grupo, demonstrando que o uso inadequado da resistência à opressão poderia comprometer os fins almejados pelo grupo desobediente. Daí a importância do instituto da desobediência civil. Concluiu que a não violência é a única "arma" política útil para combater à violência do sistema. ${ }^{102}$

Celso Lafer analisa que a desobediência civil no século $\mathrm{XX}$, conserva as influências de Henry David Thoreau e Mahatma Gandhi. De Thoreau conserva o caráter não violento da resistência individual às arbitrariedades e injustiças estatais, já de Gandhi conserva as dimensões de uma ação coletiva. ${ }^{103}$

Essas influências ficam bem claras por meio da ação de Martin Luther King Jr., que se utilizou da prática da não violência para liderar o

\footnotetext{
${ }^{101}$ Ibid. p. 59-60.

${ }^{102}$ LAFER, Celso. A Reconstrução dos Direitos Humanos: um diálogo com o pensamento de Hannah Arendt. São Paulo: Companhia das Letras,1991. p. 200.

${ }^{103}$ Ibid. p. 201.
} 
movimento dos direitos civis dos negros que lutaram contra a discriminação racial nos EUA.

\subsection{Mahatma Gandhi: A Não Violência}

Mohandas Karamchand Gandhi (1869-1948), "Grande Alma”, Mahatma Gandhi, ficou mundialmente conhecido pelo seu engajamento pacifista na busca pela efetivação dos direitos civis e políticos indianos, bem como por dedicar a sua vida em função do processo de formação do Estado indiano. ${ }^{104}$ Conforme historiado, Mahatma Gandhi nasceu no oeste da Índia, no seio de uma família abastada de administradores e comerciantes do Kâthiyâvâr, em 1869.

Formou-se em advocacia, na Inglaterra, mas foi na África do sul onde iniciou sua carreira como defensor dos interesses dos emigrantes da Índia atuando como advogado nos problemas de imigração. Foi ali que iniciou a desenvolver sua filosofia de resistência passiva contra injustiças, satyagraha, que significa a força da verdade. ${ }^{105}$

$\mathrm{Na}$ África, participou de atividades políticas liderando o movimento contra a Indian Franchise, projeto legislativo que visava limitar os direitos civis dos indianos. Diante disto, Gandhi realizou uma petição na qual reuniu dez mil assinaturas e a enviou ao secretário britânico das colônias. Liderou diversos protestos em prol dos direitos dos indianos naquele país, tendo sido preso em diversas ocasiões.

Voltou para a Índia em 1915 após notáveis conquistas e mudanças na vida dos indianos na África do Sul; fundou o Congresso dos Indianos de Natal e, em poucos anos, tornou-se uma das personalidades de maior prestígio local.

De volta à Índia, não tardou para que aplicasse sua filosofia nãoviolenta assumindo a liderança da luta pela independência do seu país.

\footnotetext{
${ }^{104}$ COSTA, Nelson Nery. Ciência Política. 3a . edição. Rio de Janeiro: Forense, 2012, p. 573/574. ${ }^{105}$ ATTENBOROUGH, Richard. As Palavras de Gandhi. Tradução A.B. Pinheiro de Lemos. Rio de Janeiro: Record, 1982, p. 8
} 
Gandhi liderou o movimento indiano pacífico e não-violento com o propósito de conquistar autonomia política através de campanhas de desobediência civil, como a caminhada pelo sal (Satyagraha).

A Satyagraha, foi uma marcha realizada por milhares de pessoas até a praia, tinha por objetivo extinguir o imposto do sal, que era monopólio dos britânicos e ficou famosa pois, através dela, que se manifestou como um ato de protesto e resistência pacífica juntamente com a prática do jejum individual, realizado por Mahatma Gandhi, foram diretamente responsáveis pela libertação da Índia da dominação exercida pela metrópole.

Foi neste processo de atuação que Mahatma Gandhi teve contato com a obra "Desobediência Civil", de Henry David Thoreau - em 1902 - a qual lhe influenciou na construção de suas estratégias políticas em busca dos direitos indianos, e mais tarde a independência perante a metrópole. ${ }^{106}$ Para Gandhi, a fórmula utilizada por Thoreau, com restrições à atuação estatal, seria o ideal para que o poder político fosse visto como um meio de viabilizar melhoras nas condições de vida da população. A democracia com participação popular nos negócios públicos apresentava-se como a melhor forma de escolha dos governantes por eleição livre e meio não violento. ${ }^{107}$

No entanto, Gandhi também enxergava que embora o regime democrático fosse o mais adequado este apresentava falhas. Observando que: em primeiro lugar, embora inserido na sociedade sujeitando-se às limitações dela decorrentes, a liberdade individual de cada cidadão deveria ser preservada, principalmente no que tange a liberdade de opinião e de comportamento político; em segundo lugar, o governo majoritário não poderia sacrificar as vontades e interesses de uma minoria, que, as vezes poderia significar $49,99 \%$ dos cidadãos. ${ }^{108}$

A ação desobediente de Gandhi expressava-se em duas táticas: a satyâgraha, que era representada pela resistência pacífica exercida através

\footnotetext{
${ }^{106}$ COSTA, Nelson Nery. Ciência Política. $3^{\text {a }}$. edição. Rio de Janeiro: Forense, 2012, p. 574

${ }^{107}$ COSTA, Nelson Nery. Teoria e Realidade da Desobediência Civil. 1ª . edição. Rio de Janeiro: Forense, 1990. p. 33.

${ }^{108}$ COSTA, Nelson Nery. Teoria e Realidade da Desobediência Civil. 1 ${ }^{\text {a }}$. edição. Rio de Janeiro: Forense, 1990. p. 33.
} 
de manifestações não-violentas, que pleiteavam os direitos civis e políticos; e a asahayoh, que era representada pela não-cooperação, na qual os desobedientes boicotavam a compra de determinados produtos para impactar os produtores capitalistas, a com o objetivo de conquistar direitos sociais.

Gandhi defendia que o único caminho eficaz para mudanças sociais era a não-violência, ahimsa, uma vez que considerava que a violência até poderia garantir a proteção dos direitos materiais, mas somente a nãoviolência seria capaz de garantir a honra e os direitos dos homens. Ainda assim, reconhecia as dificuldades enfrentadas pelos praticantes da filosofia da não-violência que além da coragem também exigia uma dedicada preparação para os praticantes absterem-se de reagir diante do uso da força dos adversários.

O pacifista indiano via a desobediência civil como um instrumento a exercício da cidadania, uma vez que, de forma pacífica buscava modificar legislações e práticas estatais. Além disso, a resistência não violenta funcionava como um meio de manutenção da honra dos indivíduos resistentes, permitindo a atuação direta da maioria e das minorias frente ao Estado, como foi o caso da Índia naquele momento frente ao Império Britânico. Em suas palavras, "A resistência civil é o meio mais eficaz de exprimir a angústia da alma e o mais eloquente para protestar contra a manutenção no poder de um Estado nocivo". ${ }^{109}$

A independência da Índia foi conquistada em 1947 após muita luta e resistência. Embora houvesse quem cometesse atos de violência, Gandhi sempre se manteve fiel às suas convicções. Quando havia luta Gandhi jejuava até que cessasse. Gandhi foi assassinado a tiros em janeiro de 1948, aos 79 anos. ${ }^{110}$

\footnotetext{
${ }^{109}$ COSTA, Nelson Nery. Teoria e Realidade da Desobediência Civil. $1^{\mathrm{a}}$. edição. Rio de Janeiro: Forense, 1990. p. 36.

${ }^{110}$ ATTENBOROUGH, Richard. As Palavras de Gandhi. Tradução A.B. Pinheiro de Lemos. Rio de Janeiro: Record, 1982, p. 8-9.
} 


\subsection{Martin Luther King Jr.: o Exercício Coletivo da Desobediência Civil}

Antes de nos debruçarmos sobre o tema do movimento pela luta dos direitos civis dos negros contra a discriminação racial nos EUA, liderada por Martin Luther King Jr., imperioso se faz realizarmos uma pequena digressão no tempo para que se compreenda os fatores históricos que ensejaram tais acontecimentos.

\subsubsection{Aspectos Históricos}

Entre 1861 e 1865 ocorreu nos Estados Unidos uma Guerra Civil também chamada de Guerra de secessão, foi um conflito militar que tinha de um lado os estados do Sul (Confederados), e do outro os estados do Norte (União).

A guerra teria se originado das existentes divergências ideológicas e econômicas decorrentes da escravidão. Enquanto os estados do sul tinham uma economia baseado na mão de obra escrava, os estados do norte defendiam a abolição da escravidão. Após 5 anos de guerra os estados do norte saírem vencedores e foi dado fim a escravidão.

Finda a Guerra Civil, os Estados Unidos realizaram três emendas que inicialmente se mostravam revolucionárias: emenda XIII (1865); emenda XIV (1868), que aprovou a Equal Protection Of The Law; e emenda XV (1870); as quais, aboliram a escravidão, reconheceram a igualdade de todos perante a lei e garantiram a todos o direito de voto.

Nesse sentido, mister destacar a décima quarta emenda:

Todas as pessoas nascidas ou naturalizadas nos Estados Unidos e sujeitas a sua jurisdição são cidadãos dos Estados Unidos e do Estado onde tiver residência. Nenhum Estado poderá fazer ou executar leis restringindo os privilégios ou as imunidades dos cidadãos dos Estados Unidos, nem poderá privar qualquer pessoa de sua vida, liberdade ou bens sem o devido processo 
legal, ou negar a qualquer pessoa sob sua jurisdição igual

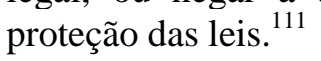

No entanto, no mesmo ano de aprovação da décima quarta emenda (ano de 1868) os mesmos parlamentares que votaram a equal protection of the Law permitiram a criação de leis segregacionistas pelo governo, a partir disso, leis que separavam lugares para brancos dos lugares de negros não seriam inconstitucionais. Contudo, tão logo houve vários estados sulistas aprovando leis segregacionistas que ficaram conhecidas com "Jim Crow Laws" $" 112$

Em 1896, um caso emblemático que ficou conhecido como "Plessy vs. Ferguson" foi levado a Corte Suprema. Em debate, foi analisada a constitucionalidade de uma dessas leis segregacionistas.

No referido caso, a Suprema Corte, com apenas um voto contrário, decidiu que a reserva de acomodações "separadas, mas iguais" para negros nos transportes ferroviários seria compatível com o princípio da igualdade, já que essa teria sido a intenção dos legisladores que aprovaram a cláusula da igualdade.

A partir desse momento, foi desenvolvida a doutrina "iguais, mas separados" (equal but separate). ${ }^{113}$

Segundo George Marmelstein, ocorreu uma "legalização" da segregação racial nos EUA, confirmada pelo Caso Plessy vs. Ferguson, muito se assemelha ao regime de apartheid que vigorou na África do Sul até os anos 90:

\footnotetext{
111 XIV Emenda da Constituição Norte-Americana. Disponível em: <http://www.uel.br/pessoal/jneto/gradua/historia/recdida/ConstituicaoEUARecDidaPESSOALJNE TO.pdf> Acesso em: 17.11.2018.

112 Disponível em: https://direitasja.com.br/tag/jim-crow-laws/ Acesso em: 14.06.2018. Observação: O nome "Jim Crow" foi dado em "homenagem" a um comediante norte-americano chamado Thomas D. Ride que costumava se pintar de preto para ridicularizar os negros com o personagem "Jim Crow". Disponível em: $<$ https://direitosfundamentais.net/2008/10/23/as-pioresdecisoes-da-suprema-corte-dos-eua-ii-caso-plessy-vs-ferguson/> . Acesso em: 14.06.2018.

113 Disponível em:< https://direitosfundamentais.net/2008/10/23/as-piores-decisoes-da-supremacorte-dos-eua-ii-caso-plessy-vs-ferguson/> . Acesso em: 14.06.2018.
} 
Era um sistema cruel para os negros, já que eles ficavam oficialmente excluídos das mesmas vantagens públicas e privadas concedidas aos cidadãos brancos. Não tinham o mesmo acesso à educação, aos clubes (lazer), aos meios de transporte, aos cinemas, ao trabalho, aos restaurantes e por aí vai. Eram cidadãos de segunda classe e até hoje isso se reflete na estrutura sócio-econômica daqueles países, em que os negros, em sua maioria, costumam morar em "guetos" pouco desenvolvidos, possuem baixa escolaridade e exercem funções quase sempre braçais de pouca rentabilidade. ${ }^{114}$

Diante disto, mesmo um século após o fim da Guerra Civil norteamericana e a abolição da escravidão, em 1955 ainda vigoravam nos estados do Sul legislações segregacionistas, que perpetuavam a discriminação em todos os lugares, até mesmo nas escolas, bibliotecas públicas, nos parques e meios de transportes.

\subsubsection{Ação Direta}

Martin Luther King Jr. (1929-1968), nasceu em Atlanta, na Geórgia, Estados Unidos, filho de um pastor da Igreja batista Ebenézer. Estudou em Groler Seminary, de onde saiu pastor. Completou a graduação nas Universidades de Harvard e Pensilvânia, e doutorou-se em Filosofia e Teologia na Universidade de Boston. Posteriormente fundou e presidiu a Conferência Sulista de Liderança Cristã. ${ }^{115}$

Ficou mundialmente conhecido pela sua luta em prol dos princípios de liberdade e igualdade, e pelos direitos civis para os negros e mulheres na América, se tornando um dos mais importantes líderes dos movimentos pelos direitos civis dos negros nos Estados Unidos. Recebeu o Prêmio Nobel da Paz de 1964 por conta do movimento pacífico contra o preconceito racial.

A luta de Martin Luther King Jr. pelos direitos civis nos Estados Unidos teve início no episódio que ficou conhecido como Milagre de

\footnotetext{
114 Ibid.

${ }^{115}$ COSTA, Nelson Nery. Ciência Política. $3^{\mathrm{a}}$. edição. Rio de Janeiro: Forense, 2012. p. 684.
} 
Montgomery. Em $1^{\circ}$ de dezembro de 1955, quando a Sra. Rosa Parks, uma mulher negra, foi presa por se recusar a levantar do lugar onde estava sentada no ônibus para ceder o lugar a um homem branco - como previa a lei segregacionista. ${ }^{116}$

O ocorrido com Rosa Parks não havia sido o primeiro ato de discriminação contra os negros americanos e era notório que não seria o último.

Os negros, diante do acúmulo de injustiças e indignidades sofridas, cansados de aguentar o tratamento que lhes era reservado, viram no acontecimento um estopim, colocando o debate racial em maior nível de atenção. Martin Luther King Jr., em conjunto com outros ativistas pela luta pelos direitos civis dos negros, organizaram o movimento de boicote aos ônibus de Montgomery - um movimento de resistência pacífico, sem violência, exercício da desobediência civil - a fim de pressionar o governo a acabar com a discriminação que havia contra os negros no transporte público dos Estados Unidos. Para disseminar a ideia, prepararam a seguinte mensagem:

Segunda-feira, 5 de dezembro, não vá de ônibus para o trabalho, para a cidade, para a escola ou para qualquer outro lugar. Outra mulher negra foi detida e posta na cadeia por ter se recusado a ceder seu lugar no ônibus. Segunda feira não pegue ônibus para o trabalho, para a cidade, para a escola ou para qualquer outro lugar. Se trabalha, vá de táxi, pegue uma carona ou vá a pé. ${ }^{117}$

Segundo sua autobiografia, o pastor King fez uma autorreflexão do ato de desobediência civil que estava na iminência de ocorrer, questionouse, se o ato seria justo, ético e cristão (o que para ele era uma preocupação, uma vez que era religioso). Inspirado pelo texto de Thoreau, concluiu:

\footnotetext{
${ }^{116}$ KING JR, Martin Luther. A Autobiografia de Martin Luther King Jr. Organização Clayborne Carson. Tradução de Carlos Alberto Medeiros. 1 ${ }^{a}$ edição. Rio de Janeiro: Zahar, 2014. p.69

${ }^{117}$ Ibid. p. 71.
} 
(...) o que realmente estávamos fazendo era deixar de cooperar com um sistema perverso e não meramente retirar nosso apoio à empresa de ônibus. (...) comecei a pensar em 'A desobediência civil' de Thoreau. Fiquei convencido de que o que estávamos nos preparando para fazer em Montgomery tinha relação com o que fora explicitado por Thoreau. Estávamos apenas dizendo à comunidade branca: Não vamos mais dar nossa colaboração a esse sistema perverso. A partir desse momento, passei a conceber nosso movimento como um ato popular de não cooperação. ${ }^{118}$

Martin Luther King viu que o episódio com a Sra. Parks teve um duplo impacto: foi um fato desencadeador que levou os negros a uma ação positiva; e foi um teste de validade da própria legislação segregacionista. E isso foi de suma importância, pois Martin Luther King Jr. percebeu que sem uma ação positiva a segregação não iria acabar, e os negros nunca seriam tratados com respeito e dignidade. Após um encontro com as autoridades municipais e os administradores das empresas de ônibus, Martin Luther King Jr. refletiu:

Acreditava que os privilegiados abririam mão de seus privilégios se isso lhes fosse pedido. Essa experiência, contudo, me ensinou uma lição. Passei a perceber que ninguém abandona seus privilégios sem uma forte resistência. Percebi também que o propósito subjacente da segregação era oprimir e explorar os segregados, e não apenas mantê-los separados. Mesmo pedindo por justiça dentro das leis segregacionistas, os 'poderes constituídos' não estavam dispostos a nos atender. Justiça e igualdade, percebi, nunca viriam enquanto a segregação permanecesse, pois o propósito básico desta era perpetuar a injustiça e a desigualdade. ${ }^{119}$

Martin Luther King também se inspirou em Mahatma Gandhi cujos escritos eram claramente influenciados por Henry David Thoreau e Leon Tolstoi.

Para Nelson Nery, Gandhi trouxe uma nova abordagem para a teoria da desobediência civil, devido a seu caráter prático e eficiente e porque introduziu a filosofia da não-violência, ainda, realçando os aspectos morais da resistência pois para Gandhi:

${ }^{118}$ Ibid. p. 73 .
${ }^{119}$ Ibid. p. 92. 
(...) a filosofia da não violência, ahimsa, como o único caminho eficaz para qualquer mudança social, em um mundo cercado de violência e arbitrariedade. A resistência passiva, assim, era um método que permitia defender todo o direito que se encontrasse ameaçado, fazendo recair sobre si os sofrimentos que pudessem dela resultar. A violência poderia protege os bens materiais, mas a não violência era indispensável para garantir a honra e os direitos dos homens. ${ }^{120}$

Desde o início, o movimento pelos direitos civis dos negros liderado por Martin Luther King Jr. foi orientado pela resistência não violenta, não cooperação ou resistência passiva.

É importante frisar que King Jr. defendia a não violência até mesmo diante das ameaças sofridas e da repressão violenta da polícia. Martin Luther King Jr. foi uma das vítimas da operação policial de "endurecimento", sendo preso por dirigir a 48 quilômetros por hora numa área em que o limite era 30 - onde percebeu que até na cadeia as regras de segregação não eram quebradas, uma vez que negros e brancos eram presos em celas separadas - e também sofreu muitos atentados, juntamente com sua família, sendo "presenteado" com bombas em sua residência ${ }^{121}$.

Martin Luther King Jr. elaborou o texto "Significado do boicote", citado no New York Times, em 24.02.1956, onde mais uma vez adota paradigmas de justiça para apoiar o movimento, e proclama palavras de amor para unir o movimento sem violência:

Há os que tentariam fazer disto uma campanha de ódio. Esta não é uma guerra entre brancos e negros, mas um conflito entre justiça e injustiça. Isto é maior que uma revolta da raça negra contra a branca. Estamos tentando melhorar não o negro de Montgomery, mas Montgomery como um todo. Se formos presos todos os dias, se formos explorados todos os dias, se formos espezinhados todos os dias, nunca deixe ninguém rebaixá-los a tal ponto que vocês venham a odiá-lo.(...) $)^{122}$

\footnotetext{
${ }^{120}$ COSTA, Nelson Nery. Teoria e Realidade da Desobediência Civil. $1^{\text {a }}$. edição. Rio de Janeiro: Forense, 1990. p. 35.

${ }^{121}$ KING JR, Martin Luther. A Autobiografia de Martin Luther King Jr. Organização Clayborne Carson. Tradução de Carlos Alberto Medeiros. $1^{\text {a }}$ edição. Rio de Janeiro: Zahar, 2014. p. 105.

${ }^{122}$ KING JR, Martin Luther. A Autobiografia de Martin Luther King Jr. Organização Clayborne Carson. Tradução de Carlos Alberto Medeiros. $1^{\text {a }}$ edição. Rio de Janeiro: Zahar, 2014. p.105.
} 
Quando os opositores do movimento em prol dos direitos civis dos negros percebem que a violência contra eles imputada não seria capaz de enfraquecer o protesto, recorreramm às prisões em massa. Passou-se a alegar a existência de uma antiga lei estadual que vedava os boicotes, e ameaçaram: quem infringisse a lei seria preso. E assim, mais de uma centena de negros que pacificamente exerciam seu direito de resistência foram presos pelo simples ato de desobediência civil, por boicotarem os ônibus $^{123}$.

Henry David Thoreau, quando foi preso pelo não pagamento dos impostos devidos, não resistiu à prisão, muito pelo contrário, orgulhou-se, pois via nesse ato, a aceitação da punição uma forma de expor a todos que não era um rebelde, e se por agir conforme seus ideais de justiça, precisasse ser preso, a isso não se oporia. Em seu ensaio da "Desobediência Civil" fica bem claro que ele acreditava que, sendo a prisão o lugar que o Estado injusto reservava aos homens justos, por terem se recusado a pagar impostos, era lá então onde deveria ficar.

E, assim como Thoreau não resistiu à prisão, também não resistiram os negros, eles tinham orgulho de seus crimes, "na cadeia, prevalecia quase que uma atmosfera de dia festivo. As pessoas haviam acorrido para serem presas (...) ninguém tentará evadir-se da prisão." 124

Após um ano de boicote aos ônibus, um ano em que negros, homens e mulheres, idosos, jovens e crianças caminharam até suas escolas, trabalhos, e lazer, como forma de protesto, em 13 de novembro de 1956 saiu a determinação de integração dos ônibus em Montgomery, e a lei segregacionista foi derrubada. E assim, foi conquistada a primeira de muitas vitórias do movimento de resistência não violento liderado por Martin Luther king em prol dos direitos civis dos negros nas cidades americanas.

\footnotetext{
${ }^{123}$ KING JR, Martin Luther. A Autobiografia de Martin Luther King Jr. Organização Clayborne Carson. Tradução de Carlos Alberto Medeiros. $1^{\text {a }}$ edição. Rio de Janeiro: Zahar, 2014. p. 105.

${ }^{124}$ KING JR, Martin Luther. A Autobiografia de Martin Luther King Jr. Organização Clayborne Carson. Tradução de Carlos Alberto Medeiros. $1^{\mathrm{a}}$ edição. Rio de Janeiro: Zahar, 2014. p. 111.
} 
Martin Luther king, a partir da vitória de Montgomery, continua a liderar outros movimentos, como o de Birminghan - maior cidade industrial do Sul do país, uma cidade rigorosamente segregada, onde teve um movimento de resistência bem mais amplo - que também foi pautado na não violência, o que era uma tática do movimento. A desobediência civil colocava o Estado na seguinte posição: se permitisse que os manifestantes agissem livremente, admitiam que suas reinvindicações eram legítimas; ao proibirem o movimento exporiam as injustiças do governo. Essa tática permitiu que aos poucos o movimento fosse ganhando notoriedade e apoio nacionalmente e internacionalmente e isso permitiu a conquista dos direitos civis e políticos dos negros nos Estados Unidos.

Nas palavras de Martin Luther King Jr.:

(...) não pode haver dúvidas, mesmo nos recônditos das mentes mais preconceituosas, de que a Marcha sobre Washington de 28 de agosto foi a mais importante e comovente demonstração de liberdade e justiça em toda a história deste país."

Para o mundo, o impacto não foi diferente, a Marcha sobre Washington, celebrada em de 28 de agosto de 1963, exigia igualdade para todos os cidadãos perante a lei. Liderada pelo reverendo Martin Luther king Jr., foi a maior manifestação em defesa da igualdade racial na história dos Estados Unidos.

Levou à capital de Washington mais de 200 mil pessoas, negras e brancas, ao memorial de Abraham Lincoln. À marcha sobre Washington sucedeu um período de muitos protestos em Birmingham, no Estado do Alabama, onde cães policiais feriram manifestantes e potentes jatos de água foram usados em crianças. Haviam previsões de retaliações ${ }^{126}$. Por isso, a atmosfera era de tensão, no entanto, isso não impediu a realização da marcha.

\footnotetext{
${ }^{125}$ KING JR, Martin Luther. A Autobiografia de Martin Luther King Jr. Organização Clayborne Carson. Tradução de Carlos Alberto Medeiros. 1a edição. Rio de Janeiro: Zahar, 2014. p. 262.

${ }^{126}$ KING JR, Martin Luther. A Autobiografia de Martin Luther King Jr. Organização Clayborne Carson. Tradução de Carlos Alberto Medeiros. 1ª edição. Rio de Janeiro: Zahar, 2014. p.105.
} 
A marcha contou com a participação de negros e brancos, inclusive de igrejas brancas. Um escritor disse que a marcha "aproximou mais as três principais religiões do país do que qualquer outro assunto na história desta nação em tempos de paz" ${ }^{\text {,127 }}$.Martin Luther King Jr., observou:

(...)nenhum fator entre aqueles que emergiram no verão de 1963 deu tanto ímpeto à revolução em curso e a seu objetivo de sensibilizar a consciência da nação quanto a decisão dos líderes religiosos deste país de desafiarem a tradição e se tornarem parte integrante da luta do negro por seus direitos ${ }^{128}$.

Diante da multidão que lhe assistia, Martin Luther King Jr., bem no meio da escadaria sobre os degraus do Lincoln Memorial, proferiu seu mais famoso discurso "I have a dream" (Eu tenho um sonho):

(...) Cem anos atrás, um grande americano, sob cuja sombra simbólica nos encontramos, assinou a Proclamação de Emancipação. Esse importante decreto veio como um grande farol de esperança para milhões de escravos negros que tinham sido queimados nas chamas da injustiça intimidante. (...) Mas cem anos depois o negro ainda não está livre. Cem anos depois, a vida do negro ainda é tristemente deformada pelas algemas da segregação e pelas cadeias da discriminação. (...) Assim, viemos aqui hoje para dramatizar uma condição vergonhosa. De certo modo, viemos à capital de nossa nação para trocar um cheque. Quando os arquitetos de nossa república escreveram as magníficas palavras da Constituição e da Declaração de Independência, estavam assinando uma nota promissória da qual todo americano seria herdeiro. Essa nota era uma promessa de que todos os homens, sim, os homens negros e os homens brancos, teriam garantidos os direitos inalienáveis à "Vida, à Liberdade e à busca da Felicidade". Hoje é obvio que a América não resgatou sua promissória no que se refere a seus cidadãos negros. (...) Este é o momento de transformar em realidade as promessas de democracia. Este é o momento de ascender do vale desolado da segregação ao caminho iluminado da justiça racial. (...) Seria fatal para a nação negligenciar a urgência desse momento. (...) Mas há algo que eu tenho a dizer ao meu povo (...) não devemos arcar com a culpa por ações ilegais. Não vamos satisfazer nossa sede de liberdade bebendo da xícara de amargura e ódio. (...) Não devemos permitir que nosso protesto criativo degenere em violência física. (...) Não nos deixemos cair no vale da desesperança. Eu lhes digo agora, meus amigos, que embora enfrentemos as dificuldades atuais e futuras, eu ainda tenho um sonho. (...) Eu tenho um sonho de que um dia esta nação vai levantar-se e sustentar o verdadeiro significado

${ }^{127}$ Ibid. 267.

${ }^{128}$ Ibid. 267. 
de sua crença - consideramos como verdades evidentes por si mesmas que todos os homens são criados iguais. (...) ${ }^{129}$

Em virtude das repercussões causadas pelas manifestações não violentas que ocorreram, lideradas por Martin Luther King Jr., e a incansável luta das mulheres e homens negros em prol de seus direitos civis e políticos nos EUA, foram conquistadas a aprovação de duas leis históricas que puseram fim à discriminação racial nos Estados Unidos: a Lei dos Direitos Civis de 1964 (Civil Rights Act); e a Lei do Direito de Voto de 1965 (Voting Rights Act).

Martin Luther King Jr., cujos esforços foram mundialmente reconhecidos, lhe credenciando o Premio Nobel da Paz de 1964, provou para o mundo a possibilidade de exercício do direito de resistência de forma pacífica e não violenta; uma vez que, a partir do movimento de desobediência civil que liderou, pautado em suas crenças religiosas, viu juntamente com toda a população negra estadunidense, a igualdade de tratamento sendo pouco a pouco conquistada.

O sucesso de Martin Luther King, na liderança do movimento negro, juntamente com as conquistas alcançadas, lhe rendeu inimigos. Em 4 de abril de 1968, o pastor Martin Luther King Jr. foi assassinado. No entanto, ainda vive o seu legado, tanto para a população negra de todo o mundo, que até hoje colhe os frutos de seus feitos e busca nas obras de King inspiração para seguir lutando, bem como o instituto da desobediência civil que com seus inscritos ganha novo desenvolvimento teórico.

\subsection{Conclusão do Capítulo}

Do exposto, o conceito de desobediência civil, não nasce junto com o surgimento do instituto do direito de resistência. É resultado de um avanço

${ }^{129}$ Ibid. p. 268-272. 
do instituto, sendo classificado como uma espécie do direito de resistência, funcionando como um dos meios de exercício do ius resistendi.

Em uma sociedade moderna, plural, constituída por diversos grupos minoritários, é de suma importância nos debruçarmos sobre o instituto do direito de resistência a partir da desobediência civil que, introduzida por Henry David Thoreau, traz a possibilidade de resistência individual ou de minorias, uma vez que dispensa a necessidade de comoção da maioria e daqueles que detém o poder para seu exercício. Isso pode ser claramente expressado pela atuação de Mahatma Gandhi e do pastor Martin Luther King Jr..

Gandhi, inspirado em Henry Thoreau, renovou os aspectos da teoria da desobediência civil, a partir da sua filosofia, devido a seu caráter prático e eficiente; bem como, por ter introduzido os aspectos morais da resistência não violenta.

O indiano jamais afastou-se de sua convicção de não-violência e tolerância religiosa. Tão memorável quanto o pastor King, um homem negro, que na década de 1960, liderando homens e mulheres negras nos Estados Unidos que, cansados do tratamento preconceituoso que lhes era destinado, conseguiram, a partir de um movimento de desobediência civil, adotando a não violência, mostrarem ao mundo a eficácia de um movimento de resistência pacífico, sem causar guerra e destruição.

Ambos os lideres pacifista conseguiram provar a força da vontade humana, fé e perseverança, sendo sempre fiéis aos seus preceitos de nãoviolência. 


\section{O DIREITO DE RESISTÊNCIA E A DESOBEDIÊNCIA CIVIL NO ORDENAMENTO JURÍDICO BRASILEIRO}

No art. $1^{\text {o }}$ da Constituição da República Federativa do Brasil de $1988^{130}$ constatamos uma promessa de construção de um Estado Democrático de Direito. No ano em que se completam 30 anos da promulgação da atual constituição; e decorridos 15 anos desde a elaboração da obra "Direito de Resistência Constitucional" de Buzanello, infelizmente, o que lá se expõe ${ }^{131}$ ainda não vale para os dias atuais: o Brasil consolida vagarosamente o processo democrático e de efetivação dos direitos fundamentais ao qual se comprometeu assegurar.

Além disso, mister sinalizar que no ordenamento jurídico pátrio paira em parcela da população o temor de possível retrocesso das conquistas até aqui alcançadas diante do atual cenário político que tem gerado revolta e conflitos no país, entre os integrantes de grupos com ideologias políticas divergentes.

No mês de outubro de 2018 ocorreram no Brasil eleições presidenciais para mandato dos anos 2019 a 2022. Os candidatos ao cargo presidencial acusavam-se mutuamente de oferecerem perigo a democracia do ordenamento jurídico brasileiro.

Diante dessas acusações, vimos campanhas organizadas pelos eleitores viralizarem nas redes sociais (como facebook, twitter e instagram), bem como manifestações por todo o Brasil, ora pacífica, ora com relatos de ataques violentos e brados de discurso de ódio, proferidos em regra contra as minorias (mulheres, pobres, negros e homossexuais).

\footnotetext{
130 “Art. $1^{\text {o }}$ A República Federativa do Brasil, formada pela união indissolúvel dos Estados e Municípios e do Distrito Federal, constitui-se em Estado Democrático de Direito e tem como fundamentos (...)". Disponível em: <http://www.planalto.gov.br/ccivil_03/constituicao/constituicaocompilado.htm >, Acesso em: 28.10.2018.

${ }^{131}$ BUZANELLO, José Carlos. Direito de Resistência Constitucional. Rio de Janeiro: América Jurídica, 2002, p.202.
} 
Embora vigore no Brasil processo eleitoral democrático, isso não evita que sejam eleitos aos cargos políticos candidatos que claramente não satisfaçam o interesse de todos. Existe ainda grande insatisfação por parcela da população com os resultados obtidos das urnas. Apesar de vencedor, o futuro presidente enfrentará um árduo caminho presidencial uma vez que, apesar de ter sido eleito já conta com grupos se movimentando, em conjunto com a população, para fazerem oposição a seu futuro governo.

Em que pese a divergência, é preciso reiterar que o direito de resistência é instrumento apto a ser utilizado diante de ameaça estatal ao Estado Democrático de Direito. Nesse sentido, é claramente pertinente o que aqui se aventou.

Assim, abordar-se-á o respeito do instituto do direito de resistência e da desobediência civil no ordenamento jurídico pátrio.

Embora existentes diferentes abordagens acerca da possibilidade da licitude ou não do exercício do direito de resistência no Brasil, aqui nos guiaremos pelos ensinamentos de José Carlos Buzanello, o qual se dedicou no estudo deste tema.

\subsection{Direitos e Garantias Fundamentais na Constituição Brasileira de 1988}

No Preâmbulo da Constituição da República Federativa do Brasil de 1988, lemos:

Nós, representantes do povo brasileiro, reunidos em Assembléia Nacional Constituinte para instituir um Estado Democrático, destinado a assegurar o exercício dos direitos sociais e individuais, a liberdade, a segurança, o bem-estar, o desenvolvimento, a igualdade e a justiça como valores supremos de uma sociedade fraterna, pluralista e sem preconceitos, fundada na harmonia social e comprometida, na ordem interna e internacional, com a solução pacífica das controvérsias, promulgamos, sob a proteção de Deus, a seguinte CONSTITUIÇÃO DA REPÚBLICA FEDERATIVA DO BRASIL. ${ }^{132}$ 
Embora saibamos que o Preâmbulo da Constituição não possua força vinculante por ser desprovido de normatividade ${ }^{133}$, anuncia a dimensão democrática do novo ordenamento jurídico brasileiro ${ }^{134}$. O Preâmbulo traz os fins a que se destina esta constituição. Nesse sentido, José Afonso da Silva ao referir-se expressamente ao Preâmbulo da Constituição brasileira de 1988 nos ensina que:

O Estado Democrático de Direito destina-se a assegurar o exercício de determinados valores supremos. 'Assegurar', tem, no contexto, função de garantia dogmático-constitucional; não, porém, de garantia dos valores abstratamente considerados, mas do seu 'exercício'. Este signo desempenha, aí, função pragmática, porque, com o objetivo de 'assegurar', tem o efeito imediato de prescrever ao Estado uma ação em favor da efetiva realização dos ditos valores em direção (função diretiva) de destinatários das normas constitucionais que dão a esses valores conteúdo específico" (...). Na esteira destes valores supremos explicitados no Preâmbulo da Constituição brasileira de 1988 é que se afirma, nas normas constitucionais vigentes, o princípio jurídico da solidariedade. ${ }^{135}$

Logo, não podemos negar que a Constituição de 1988 - nascida da luta daqueles que não aceitavam mais conviver no regime militar de $1964^{136}$ - tem como premissa assegurar o exercício de direitos fundamentais que considera mínimos para a manutenção de um Estado Democrático.

O Título I da Constituição inaugura a parte dogmática do seu texto; inclui os arts. $1^{\circ}$ a $4^{\circ}$. Já no art. $1^{\circ}$ do texto constitucional temos a cidadania e a dignidade da pessoa humana recebendo o status de princípios

\footnotetext{
http://www.planalto.gov.br/ccivil_03/constituicao/constituicaocompilado.htm>, Acesso em: 28.10.2018.

133 Disponível em: <

http://redir.stf.jus.br/paginadorpub/paginador.jsp?docTP=AC\&docID=375324>， Acesso em: 28.10.2018.

${ }^{134}$ BUZANELLO, José Carlos. Direito de Resistência Constitucional. Rio de Janeiro: América Jurídica, 2002, p. 202.

135 Disponível em:

<http://redir.stf.jus.br/paginadorpub/paginador.jsp?docTP=AC\&docID=555517>, Acesso em: 28.10.2018.

136 "Que revogou direitos constitucionais fundamentais e suprimiu as liberdades públicas, principalmente pelos Atos Institucionais, encerrou-se com a Constituição Democrática de 1988." BUZANELlO, José Carlos. Direito de Resistência Constitucional. Rio de Janeiro: América Jurídica, 2002, p. 194.
} 
fundamentais do ordenamento pátrio ${ }^{137}$, indicando que são esses imprescindíveis em um Estado Democrático de Direito. ${ }^{138}$

$\mathrm{O}$ art. $3^{\circ}$ da Lei Maior elege os objetivos fundamentais da República Federativa do Brasil, quais sejam: construir uma sociedade livre, justa e solidária; garantir o desenvolvimento nacional; erradicar a pobreza e a marginalização e reduzir as desigualdades sociais e regionais; promover o bem de todos, sem preconceitos de origem, raça, sexo, cor, idade e quaisquer outras formas de discriminação.

No art. $4^{\circ}$, são estabelecidos, em dez incisos, os princípios que regem a República Federativa do Brasil em suas relações internacionais, os quais urge destacar: prevalência dos direitos humanos; autodeterminação dos povos; repúdio ao terrorismo e ao racismo; cooperação entre os povos para o progresso da humanidade; concessão de asilo político ${ }^{139}$.

Por estarmos inseridos em um Estado Democrático de Direito, os princípios fixados pela Constituição direcionam-se a toda a coletividade, sujeitando governantes e governados aos seus mandamentos, bem como as atividades legislativas, executivas e judiciárias ${ }^{140}$.

O Título II da CRFB de 88 trata dos Direitos e Garantias Fundamentais; constitui-se do art. $5^{\circ}$ ao 17 . Embora não se trate de disposição pacífica, os direitos e garantias ali tratados podem ser classificados em: I- direitos individuais (art. $5^{\circ}$ e 12 ); II- direitos políticos (arts. 14 a 16); III - direitos sociais (art. $6^{\circ}$ a 11 ); IV - direitos coletivos $\left(\operatorname{art} .5^{\circ}\right) .{ }^{141}$

No art. $5^{\circ}$ da CRFB de 88 , estabelece-se o direito constitucional de igualdade bem como garante-se aos brasileiros e estrangeiros residentes no

\footnotetext{
${ }^{137}$ Disponível em: <http://www.planalto.gov.br/ccivil_03/constituicao/constituicaocompilado.htm $>$, Acesso em: 28.10.2018.

${ }^{138}$ BUZANELLO, José Carlos. Direito de Resistência Constitucional. Rio de Janeiro: América Jurídica, 2002, p. 202-203.

${ }^{139}$ Disponível em: <http://www.planalto.gov.br/ccivil_03/constituicao/constituicaocompilado.htm $>$, Acesso em: 28.10.2018.

${ }^{140}$ BUZANELLO, José Carlos. Direito de Resistência Constitucional. Rio de Janeiro: América Jurídica, 2002, p. 203.

${ }^{141}$ FRIED, Reis. Curso Analítico de Direito Constitucional e de Teoria Geral do Estado. Rio de Janeiro: Forense, 2005, p. 146-147.
} 
país (conforme entendimento jurisprudencial dominante tais direitos são extensíveis aos não residentes que encontrem-se no Brasil $)^{142}$ a inviolabilidade do direito à vida, à liberdade, à igualdade, à segurança e à propriedade; temos ainda o extenso rol de direitos e deveres individuais e coletivos expostos em 77 incisos.

Não obstante, o $\S 2^{\circ}$ do dispositivo legal em comento preceitua que outros direitos, decorrentes do regime político democrático e dos princípios adotados, possuem a mesma proteção dos direitos expressamente previstos $^{143}$ - o que será melhor analisado em próximo tópico - in verbis: Os direitos e garantias expressos nesta Constituição não excluem outros decorrentes do regime e dos princípios por ela adotados, ou dos tratados internacionais em que a República Federativa do Brasil seja parte.

Segundo José C. Buzanello, a Constituição de 88 inova ao incluir no rol dos direitos e garantias fundamentais, não só os tradicionais direitos civis e políticos, mas também os direitos sociais. Para o autor, os direitos individuais tratam dos direitos concernentes ao conceito de pessoa humana e a autonomia dos particulares ante o Estado, como a vida, dignidade da pessoa humana, liberdade e a honra. ${ }^{144}$ Nesse mesmo sentido manifesta-se José Afonso da Silva, para quem os direitos individuais são

(...) direitos fundamentais do homem-indivíduo que são aqueles que reconhecem autonomia aos particulares, garantindo a iniciativa e independência aos indivíduos diante dos demais membros da sociedade política e do próprio Estado". ${ }^{145}$

A liberdade de pensamento assegurada pela Constituição Federal no art. $5^{\circ}$, inciso IV, subdivide-se em: liberdade de consciência (liberdade de opinião e de crença); e na liberdade de exteriorização do pensamento (liberdade de palavra e de culto). Conforme destaca Buzanello, esses são

142 HC 94.016, Rel. Min. Celso de Mello, julgamento em 16-9-2008, Segunda Turma, DJE de 272-2009.

${ }^{143}$ FRIED, Reis. Curso Analítico de Direito Constitucional e de Teoria Geral do Estado. Rio de Janeiro: Forense, 2005, p. 149.

${ }^{144}$ BUZANELLO, José Carlos. Direito de Resistência Constitucional. Rio de Janeiro: América Jurídica, 2002, p. 203.

${ }_{145}$ SILVA, José Afonso. Curso de Direito Constitucional Positivo. São Paulo: Malheiros Editores, 2014, p. 193. 
expressões dos direitos civis e políticos guiados pelos princípios da liberdade, enquanto os direitos sociais fundam-se no direito da igualdade, os quais, articulados com os direitos coletivos, provocam a emergência da justiça social ${ }^{146}$.

Já os direitos sociais, são expressão dos direitos fundamentais do homem, exigem prestações positivas por parte do Estado direta ou indiretamente, devem estar prescritas nas normas constitucionais com vistas a proporcionar melhores condições de vida aos menos favorecidos. Por estas razões, são direitos estritamente ligados ao direito de igualdade. ${ }^{147}$ Entre os quais, podemos citar: a saúde, a educação, a segurança social, a assistência aos desamparados, o acesso ao emprego e a renda, e o acesso à moradia, que constituem o maior desafio do Estado brasileiro. Conforme destaca Buzanello, é função do Estado não se afastar de: "formular políticas que alcancem essa massa humana, que conhecemos por sem-terra, sem-teto, sem-renda, sem-emprego e sem nada". ${ }^{148}$ Inclusive, a não realização do Estado da adequada distribuição ideal de justiça social, além de claramente descumprir um preceito constitucionalmente previsto, legitima política e juridicamente os movimentos sociais a exercerem o direito de resistência. ${ }^{149}$

José Afonso da Silva, assevera não constar no corpo constitucional identificação de quais seriam os direitos coletivos dentre os incisos do art. $5^{\circ},{ }^{150}$ no, entanto, destaca quais direitos são assim considerados: acesso à terra urbana e rural, para nela morar e trabalhar, o de acesso a todos ao trabalho, o direito ao transporte coletivo, à energia, ao saneamento básico, o direito ao meio ambiente sadio, bem como, a liberdade de reunião e de associação - que não são propriamente direitos coletivos, mas sim direitos

\footnotetext{
${ }^{146}$ BUZANELLO, José Carlos. Direito de Resistência Constitucional. Rio de Janeiro: América Jurídica, 2002, p. 203-204.

${ }^{147}$ SILVA, José Afonso. Curso de Direito Constitucional Positivo. São Paulo: Malheiros Editores, 2014, p. 288-289.

${ }_{148}$ BUZANELLO, José Carlos. Direito de Resistência Constitucional. Rio de Janeiro: América Jurídica, 2002, p. 204.

${ }^{149}$ BUZANELLO, José Carlos. Direito de Resistência Constitucional. Rio de Janeiro: América Jurídica, 2002, p. 204.

${ }^{150}$ SILVA, José Afonso. Curso de Direito Constitucional Positivo. São Paulo: Malheiros Editores, 2014, p. 197.
} 
individuais de expressão coletiva. ${ }^{151}$ José Carlos Buzanello também reconhece os avanços constitucionais na esfera dos direitos coletivo, nesta seara o autor destaca a função do "substituto processual" das entidades sociais e sindicais. ${ }^{152}$

Embora a classificação dos direitos políticos aqui exposta informe que estes encontram-se dispostos nos arts. 14 a 16, para José C. Buzanelllo, o direito político já é mencionado no início do texto constitucional, no art. $1^{\circ}$, parágrafo único, que prevê a natureza do poder político brasileiro, ao prescrever: "Todo o poder emana do povo, que o exerce por meio de representantes eleitos ou diretamente, nos termos desta Constituição".

Da leitura do dispositivo exposto, o regime democrático pátrio adquiriu feição mista, conjugando, a) representatividade; b) deliberativa direta. ${ }^{153}$ José Afonso da Silva define as formas de manifestações do povo no poder, na democracia: democracia direta - o povo exerce, por si só, os poderes governamentais; democracia indireta/democracia representativa - o povo outorga as funções de governo aos seus representante; democracia semidireta - é a democracia representativa com alguns institutos da participação direta do povo nas funções do governo, entre as quais, integra a democracia participativa. ${ }^{154}$

Assim como Buzanello, o autor alude que da leitura do art. $1^{\circ}$ da CRFB a Constituição brasileira tende para a democracia participativa. ${ }^{155}$

A estrutura constitucional de participação popular não se exaure no art. $1^{\circ}$ da Constituição, pelo contrário, é ratificada nos demais dispositivos que tratam dos direitos políticos, como o art. $14^{\circ}$ da CRFB: A soberania popular será exercida pelo sufrágio universal e pelo voto direto e secreto,

\footnotetext{
${ }^{151}$ SILVA, José Afonso. Curso de Direito Constitucional Positivo. São Paulo: Malheiros Editores, 2014, p. $197-198$

152 BUZANELlO, José Carlos. Direito de Resistência Constitucional. Rio de Janeiro: América Jurídica, 2002, p. 204.

${ }^{153}$ BUZANELLO, José Carlos. Direito de Resistência Constitucional. Rio de Janeiro: América Jurídica, 2002, p. 205.

${ }^{154}$ SILVA, José Afonso. Curso de Direito Constitucional Positivo. São Paulo: Malheiros Editores, 2014, p. 138.

${ }^{155}$ SILVA, José Afonso. Curso de Direito Constitucional Positivo. São Paulo: Malheiros Editores, 2014, p. 139.
} 
com valor igual para todos, e, nos termos da lei, mediante: I - plebiscito; II referendo; III - iniciativa popular.

O plebiscito é meio apto a população votar e decidir previamente uma questão política ou institucional, antes de sua formulação legislativa; O referendo embora também seja meio apto de a população votar uma questão política ou institucional, trata-se de manifestação para aprovar ou rejeitar um projeto de lei já criados pelo poder legislativo; a iniciativa popular prevê que a população submeta projeto de lei ao legislativo. ${ }^{156}$ Temos ainda a ação popular, prevista no art. $5^{\circ}$, LXXIII, da CRFB de 88 , in verbis:

(...) qualquer cidadão é parte legítima para propor ação popular que vise a anular ato lesivo ao patrimônio público ou de entidade de que o Estado participe, à moralidade administrativa, ao meio ambiente e ao patrimônio histórico e cultural, ficando o autor, salvo comprovada má-fé, isento de custas judiciais e do ônus da sucumbência.

A ação popular é um remédio constitucional o qual tem o cidadão como único legitimado ativo para o exercício de um poder de natureza essencialmente política de fiscalização, que constitui manifestação direta da soberania popular.

Como se vê, as promessas constitucionais acerca dos direitos e garantias fundamentais são numerosas. Além disso, preenche as três dimensões do Estado de Direito: juridicidade, constitucionalidade e direitos fundamentais $^{157}$.

A Constituição de 88 ainda prevê em seu art. $5^{\circ}, \S 1^{\circ}$ que os direitos e garantias têm aplicação imediata nos termos constitucionais, declarando seus status de norma de eficácia plena - são aquelas de aplicabilidade imediata, direta e integral, independem da edição de legislação infraconstitucional para sua operatividade, podendo serem exigidas desde a entrada em vigor da constituição ${ }^{158}$; e no $\S 2^{\circ}$ do dispositivo mencionado,

156 SILVA, José Afonso. Curso de Direito Constitucional Positivo. São Paulo: Malheiros Editores, 2014, p. 143-144.

${ }^{157}$ CANOTILHO, José Joaquim Gomes. Direito constitucional e Teoria da Constituição. $6^{\mathrm{a}}$ Edição. Coimbra: Almedina, 1993, p. 357-358.

${ }^{158}$ FRIED, Reis. Curso Analítico de Direito Constitucional e de Teoria Geral do Estado. Rio de 
abre a possibilidade de concretização de outros direitos que não encontram especificados no rol constitucional. ${ }^{159}$

É na esteira deste dispositivo que iniciaremos nossa discussão acerca do direito de resistência na constituição brasileira e no ordenamento pátrio.

\subsection{Análise do Direito de Resistência no Brasil}

José Carlos Buzanello assevera que o texto constitucional brasileiro assegura material e formalmente o exercício do direito de resistência ${ }^{160}$. Para o autor, a resistência constitucional apresenta-se sob o aspecto formal e material.

$\mathrm{O}$ aspecto formal refere-se aos expressos e constitucionalmente postos; e o aspecto material refere-se aos direitos que são materialmente constitucionais, como por exemplo os princípios implícitos.

Além disso, o ius resistendi constitucional exterioriza-se sob duas condições: a primeira identifica a resistência como fato empírico, a partir dos fatos sociais, como os movimentos sociais organizados que praticam a desobediência civil, ${ }^{161}$ a qual se extraí do art. $5^{\circ}, \S 2^{\circ}$ da CRFB; a segunda, respeita a normatividade das espécies constitucionais, como a objeção de consciência (art. $5^{\circ}$, VIII c/c art. 143, $\S 1^{\circ}$ da CRFB), a greve política (art. 9, da CRFB) e o princípio da autodeterminação dos povos (art. 4, III, da CRFB). Nada obstante, as espécies de resistência explícitas não inibem o exercício de outras formas de expressão do direito de resistência. ${ }^{162}$

\footnotetext{
Janeiro: Forense, 2005, p. 24.

${ }^{159}$ BUZANELLO, José Carlos. Direito de Resistência Constitucional. Rio de Janeiro: América Jurídica, 2002, p. 206.

${ }^{160}$ BUZANELLO, José Carlos. Direito de Resistência Constitucional. Rio de Janeiro: América Jurídica, 2002, p. 206.

${ }^{161}$ Prof. Pedro Figueiredo (ESG/RJ). Diário da Assembléia Nacional Constituinte. Suplementos Atas das Comissões Vol.5, 18.07.1987, p. 39, Apud BUZANELLO, José Carlos. Direito de Resistência Constitucional. Rio de Janeiro: América Jurídica, 2002, p. 207.

${ }^{162}$ BUZANELLO, José Carlos. Direito de Resistência Constitucional. Rio de Janeiro: América Jurídica, 2002, p. 207.
} 
Conforme já consignado, a Constituição brasileira reconhece expressamente em seu art. $5^{\circ}, \S 2$, outros direitos e garantias além dos expressos no texto constitucional, in verbis:

Os direitos e garantias expressos nesta Constituição não excluem outros decorrentes do regime e dos princípios por ela adotados, ou dos tratados internacionais em que a República Federativa do Brasil seja parte.

Buzanello observa que esse preceito constitucional inspirou-se na Nona Emenda da Constituição do Estado Unidos da América, a qual expressa: A enumeração de certos direitos na Constituição não poderá ser interpretada como negando ou coibindo outros direitos inerentes ao povo. $^{163}$

Além disso, este preceito esteve presente, com pequenas variações textual, em todas as Constituiçõos Republicanas Brasileiras: Constituição de 1891, art. 78; Constituição de 1934, art. 114; Constituição de 1937, art. 123; Constituição de 1946, art. 144; Constituição de 1967, art. 153, §3º; Constituição de 1988 , art. $5^{\circ}, \S 2 .{ }^{164}$

O comando constitucional presente no art. $5^{\circ}, \S 2^{\circ}$ é uma cláusula aberta, a qual consagra a tutela de direitos e garantias constitucionais, bem como é permissivo para que outros direitos decorrentes do regime político democrático brasileiro ou dos tratados internacionais em que o país seja parte.

Além disso, para Buzanello, quando o enunciado prescreve que não se excluem "outros" direitos, o que se quer dizer é que o sistema jurídico pátrio integraliza "novos" direitos em três perspectivas: uma quanto ao regime político; a segunda, em decorrência dos princípios constitucionais; a terceira, oriunda dos tratados internacionais. ${ }^{165}$ Maria Garcia partilha deste

\footnotetext{
${ }^{163}$ http://www.uel.br/pessoal/jneto/gradua/historia/recdida/ConstituicaoEUARecDidaPESSOALJN ETO.pdf Acessado em: 29.10.2018. 164 BUZANELLO, José Carlos. Direito de Resistência Constitucional. Rio de Janeiro: América Jurídica, 2002, p. 207.

${ }^{165}$ BUZANELLO, José Carlos. Direito de Resistência Constitucional. Rio de Janeiro: América Jurídica, 2002, p. 208.
} 
mesmo entendimento. Ao abordar os desdobramentos do que prescreve o art. $5^{\circ}, \S 2^{\circ}$ da CRFB, a autora aludi:

(...) deve-se reconhecer que os seus limites se mostram extremamente amplos para uma tentativa de delineá-los, mesmo ad exemplificandum: os seus limites encontram-se no regime e nos princípios consagrados na Constituição. Daí a sua amplitude, inabordável, em princípio, no estudo ora desenvolvido. ${ }^{166}$

Em que pese isto, Maria Garcia identifica que dentro dessa amplitude de direitos, há direitos que são percebidos a partir do sistema do regime e princípios adotados pela Constituição, como o direito de desobediência civil. Ainda, aduz a autora, os direitos e garantias oriundos do preceito constitucional retromencionado são aqueles que depreendem-se ou estão contidos no regime, nos princípios ou nos tratados internacionais firmados pelo Brasil. $^{167}$

Diante do exposto, cabe-nos agora abordar sucintamente as modalidades do exercício do direito de resistência explícitos na Constituição. Consecutivamente iremos discorrer sobre os aspectos da desobediência civil como exercício do direito de resistência, direito implicitamente previsto no texto constitucional.

\subsubsection{Direito de Resistência Explícito na Constituição}

A Constituição de 1988 reconhece explicitamente duas espécies de direito de resistência, a objeção de consciência e a greve política. Ambas previstas no Título II - Dos Direitos e Garantias Fundamentais, a objeção de consciência no Capítulo I - Dos Direitos e Deveres Individuais e Coletivos (art. 5, IV, VI e VIII), e a greve política no Capítulo II - Dos Direitos Sociais $\left(\operatorname{art.} 9^{\circ}\right){ }^{168}$

\footnotetext{
${ }^{166}$ GARCIA, Maria. Desobediência civil: direito fundamental. São Paulo: Editora Revista dos Tribunais, 2004, p. 235.

${ }^{167}$ GARCIA, Maria. Desobediência civil: direito fundamental. São Paulo: Editora Revista dos Tribunais, 2004, p. 235-236.

${ }^{168}$ BUZANELLO, José Carlos. Direito de Resistência Constitucional. Rio de Janeiro: América Jurídica, 2002, p. 214.
} 
In fini:

Art. 5º, IV, da CRFB de 1988: é livre a manifestação do pensamento, sendo vedado o anonimato;

Art. 5, VI, da CRFB de 1988: é inviolável a liberdade de consciência e de crença, sendo assegurado o livre exercício dos cultos religiosos e garantida, na forma da lei, a proteção aos locais de culto e a suas liturgias

Artigo 5, VIII, da CRFB de 1988: ninguém será privado de direitos por motivo de crença religiosa ou de convicção filosófica ou política, salvo se as invocar para eximir-se de obrigação legal a todos imposta e recusar-se a cumprir prestação alternativa fixada em lei;

Art. 9", da CRFB de 1988: "É assegurado o direito de greve, competindo aos trabalhadores decidir sobre a oportunidade de exercê-lo e sobre os interesses que devam por meio dele defender."

A objeção de consciência fundamenta-se na liberdade de consciência e de religião. A Constituição brasileira assegura como direito fundamental as liberdades de pensamento (5', IV, VI, CF), que se desdobram em duas: a primeira, decorre do inciso IV do art. $5^{\circ}$, traz a liberdade de consciência, compreendendo a liberdade de opinião e de crença; e a segunda, decorre do inciso $\mathrm{V}$ do art. $5^{\circ}$, assegura a liberdade de exteriorização do pensamento, abrangendo a liberdade de palavra e de culto. É nesse direito que reside a matriz político-jurídica da objeção de consciência. ${ }^{169}$

\subsubsection{Objeção de Consciência}

No capítulo dois do presente trabalho a objeção de consciência foi brevemente mencionada a fim de se destacar que embora também seja uma espécie de exercício do direito de resistência com a qual possam encontrar semelhanças com a desobediência civil, com ela não se confunde. José Carlos Buzanello define a objeção de consciência como "a recusa ao

\footnotetext{
${ }^{169}$ BUZANELLO, José Carlos. Direito de Resistência Constitucional. Rio de Janeiro: América Jurídica, 2002, p. 215.
} 
cumprimento de deveres incompatíveis com as convicções morais, políticas e filosóficas, (...)" ${ }^{170}$

Trata-se de um embate entre os preceitos morais pessoais com a norma jurídica $\operatorname{posta}^{171}$. O objetor se vê diante de ordem legal a si direcionada e sem questionar seus aspectos de legalidade se vê obrigado a não cumprir em razão da violação à suas crenças.

Jonh Rawls que também dedicou-se ao estudo do instituto do direito de resistência nos traz uma precisa definição de objeção de consciência a qual se faz imperioso transcrever:

(...)a objeção de consciência é a desobediência a uma injunção legal ou uma ordem administrativa mais ou menos direta. É uma recusa porque uma ordem nos é endereçada e, dada a natureza da situação, as autoridades sabem se a cumprimos ou não. ${ }^{172}$

Buzanello, considera-a uma modalidade do ius resistendi de baixa intensidade política (negação parcial das leis) e de alta repercussão moral. Na objeção de consciência temos uma pessoa que em razão dos seus valores morais se ver obrigada a desobedecer um preceito legal, no entanto reconhece o valor moral que tem essa norma, motivo pelo qual, geralmente o objetor não gera conflito revolucionário com o Estado. ${ }^{173} \mathrm{O}$ desobediente deseja tão somente ter preservado seu direito de não cumprir um dever legal e não que haja uma mudança no ordenamento jurídico.

John Rawls traz em sua obra alguns exemplos típicos de objeção de consciência, entre os quais, destacam-se: a recusa de um pacifista a servir às forças armadas, ou de um soldado a obedecer uma ordem que ele julga abertamente contrária à lei moral em sua aplicação num contexto de

\footnotetext{
${ }^{170}$ BUZANELLO, José Carlos. Direito de Resistência Constitucional. Rio de Janeiro: América Jurídica, 2002, p. 138.

${ }^{171}$ GARCIA, Maria. Desobediência civil: direito fundamental. São Paulo: Editora Revista dos Tribunais, 2004, p. 292.

${ }^{172}$ RAWLS, John. Uma Teoria da Justiça. Tradução: Almiro Piseta e Lenita M.R. Esteves. São Paulo: Martins Fontes, 2000. p. 408.

${ }^{173}$ BUZANELLO, José Carlos. Direito de Resistência Constitucional. Rio de Janeiro: América Jurídica, 2002, p. 138.
} 
guerra. ${ }^{174}$ No ordenamento jurídico pátrio o instituto da objeção de consciência apresenta duas perspectiva: uma como escusa genérica de consciência (art. $5^{\circ}, \mathrm{VIII}, \mathrm{CF}$ ), e, outra, como escusa restritiva ao serviço militar (art. 143, $\S 1^{\circ}, \mathrm{CF}$ ).

Da leitura do art. $5^{\circ}$, VIII, da Constituição, temos a escusa genérica da objeção de consciência:

VIII - ninguém será privado de direitos por motivo de crença religiosa ou de convicção filosófica ou política, salvo se as invocar para eximir-se de obrigação legal a todos imposta e recusar-se a cumprir prestação alternativa, fixada em lei;

Em pesquisa, foi possível identificar a recorrente busca da chancela jurisdicional para resolução de conflitos em que uma das partes invoca seu direito de objeção de consciência.

Um dos casos encontrados foi um mandado de segurança impetrado por um fiel da Igreja Adventista de Sétimo Dia com o fim de lhe assegurar a realização de prova de concurso público em horário compatível com sua fé religiosa - a qual exige o dever de guarda sabática, compreendendo o período iniciado nos crepúsculos da sexta-feira e findado no sábado; ${ }^{175}$ ainda, foi encontrada ação interposta por aluno de ensino superior pleiteando seu direito de não ser prejudicado por não frequentar as aulas em horário de sexta à noite ao sábado de manhã, com o abono das faltas no período mencionado, devido à sua crença religiosa. ${ }^{176}$

No primeiro caso mencionado, a segurança não foi provida, uma vez que o mandado de segurança foi impetrado contra o órgão do Ministério Público Federal e não contra autoridade coautora, ainda, o Supremo Tribunal Federal se declarou incompetente para o exame do mesmo. No segundo caso, em recurso de Apelação promovido pela instituição de

\footnotetext{
${ }^{174}$ RAWLS, John. Uma Teoria da Justiça. Tradução: Almiro Piseta e Lenita M.R. Esteves. São Paulo: Martins Fontes, 2000. p. 408.

175 Disponível em: https://stf.jusbrasil.com.br/jurisprudencia/15809827/mandado-de-segurancams-28981-df-stf, Acessado em: 31.10.2018.

176 Disponível em: https://tj-sp.jusbrasil.com.br/jurisprudencia/21996433/apelacao-apl39830320098260160-sp-0003983-0320098260160-tjsp/inteiro-teor-110489935?ref=juris-tabs, Acessado em: 31.10.2018.
} 
ensino, insatisfeita com decisão favorável ao autor em primeiro grau, foi improvido.

Em decisão, manifestou-se o Desembargador relator pela manutenção integral da sentença, tendo em vista que houve violação do princípio da boa-fé objetiva por conduta contraditória da apelante, que resolveu deixar de respeitar a fé religiosa do apelado.

A objeção de consciência especial está prevista no art. $143, \S 1^{\circ}$, da Constituição, in verbis:

O serviço militar é obrigatório nos termos da lei. § $1^{\circ}$ Às Forças Armadas compete, na forma da lei, atribuir serviço alternativo aos que, em tempo de paz, após alistados, alegarem imperativo de consciência, entendendo-se como tal o decorrente de crença religiosa e de convicção filosófica ou política, para se eximirem de atividades de caráter essencialmente militar.

Além da disposição constitucional, a objeção de consciência especial foi regulamentada por legislação ordinária, Lei ${ }^{\circ}$ 8.239, de 04.10.91 regulamenta o art. 143, $\S \S 1^{\circ}$ e $2^{\circ}$ da Constituição Federal, que dispõem sobre a prestação de Serviço Alternativo ao Serviço Militar Obrigatório. ${ }^{177}$

A constituição assegura o direito de objeção de consciência, e a lei pode estabelecer prestação alternativa a ser cumprida pelo objetor, que, por certo, há de ser compatível com suas convicções morais e/ou religiosas. Oferecida a prestação alternativa o objetor não pode se recusar de cumprila, sob pena de se sujeitar as penalidades estatuídas em lei, qual seja, suspensão de seus direitos políticos, previsto no art. $5^{\circ}$, IV, da Constituição: "É vedada a cassação de direitos políticos, cuja perda ou suspensão só se dará nos casos de: IV - recusa de cumprir obrigação a todos imposta ou prestação alternativa, nos termos do art. $5^{\circ}$, VIII". ${ }^{178}$

O estabelecimento da objeção de consciência no texto constitucional, no rol de Direitos e Garantias Fundamentais deixa claro o propósito pluralista e democrático a que se empenhou a Constituição brasileira, em

177 Disponível em: http://www.planalto.gov.br/ccivil_03/LEIS/L8239.htm, Acessado em: 31.10.2018.

${ }^{178}$ BUZANELLO, José Carlos. Direito de Resistência Constitucional. Rio de Janeiro: América Jurídica, 2002, p. 217. 
conformidade com a Declaração dos Direitos do Homem da ONU, a qual prevê em seu art. XVIII: ${ }^{179}$

Todo ser humano tem direito à liberdade de pensamento, consciência e religião; este direito inclui a liberdade de mudar de religião ou crença e a liberdade de manifestar essa religião ou crença, pelo ensino, pela prática, pelo culto e pela observância, em público ou em particular. ${ }^{180}$

\subsubsection{Greve Política}

O direito de greve é permitido no ordenamento jurídico pátrio (art. $9^{\circ}$ da CRFB) e é assegurada como direito fundamental. Esta pode ser definida como "a suspensão coletiva, temporária e pacífica, total ou parcial, de prestação pessoal de serviços a empregador" ${ }^{\text {"181 }}$. A constituição autoriza, e a Lei ${ }^{\circ} 7.783$, de 28 de junho de 1989 regula, que os trabalhadores realizem greves trabalhistas, com vistas a melhores condições de trabalho; ainda, a greve política, com o fim de melhorias junto ao poder público. ${ }^{182}$

Amauri Mascaro identifica a greve como um direito individual de exercício coletivo, manifestando-se como autodefesa; sendo a forma mais primitiva de solução de conflitos. $\mathrm{O}$ autor destaca ser seu diferencial a ausência de juiz distinto das partes para decidir e impor sua decisão às partes, quando na verdade o que ocorre é a imposição de vontade de uma parte à outra. ${ }^{183}$ A greve funciona como uma pressão; os grevistas com vistas a terem seus pleitos atendidos paralisam o trabalho e só retornam em caso de terem suas pautas acatadas ou mediante acordo.

\footnotetext{
${ }^{179}$ BUZANELLO, José Carlos. Direito de Resistência Constitucional. Rio de Janeiro: América Jurídica, 2002, p. 217.

${ }^{180}$ Disponível em: https://nacoesunidas.org/wp-content/uploads/2018/10/DUDH.pdf > Acessado em: 31.10.2018.

${ }_{181}$ Art. $2^{\circ}$ da Lei $\mathrm{n}^{\mathrm{o}} 7.783$, de 28 de junho de 1989. Disponível em: http://www.planalto.gov.br/ccivil_03/LEIS/L7783.htm

${ }^{182}$ BUZANELLO, José Carlos. Direito de Resistência Constitucional. Rio de Janeiro: América Jurídica, 2002, p. 219.

${ }^{183}$ NASCIMENTO, Amauri Mascaro Curso de direito do trabalho. 29. ed. - São Paulo : Saraiva, 2014. p. 1076-1077.
} 
O fundamento da greve como direito está no princípio da liberdade de trabalho. Uma pessoa não pode ser constrangida a trabalhar contra a sua vontade e em desacordo com as suas pretensões. Se assim fosse, estaria irremediavelmente comprometida a liberdade de trabalho, valor central que divide dois períodos da história, a escravidão e o trabalho livre. O trabalho não se desvincula da pessoa que o presta e está intimamente ligado à personalidade. ${ }^{184}$

Como se vê, o direito de greve deriva do direito constitucional de liberdade. No entanto, não se trata de um simples direito fundamental do trabalhador, mas é instrumento apto a concretização de seus direitos e interesses coletivo ${ }^{185}$.

O texto constitucional prescreve:

Art. $9^{\circ} E$ assegurado o direito de greve, competindo aos trabalhadores decidir sobre a oportunidade de exercê-lo e sobre os interesses que devam por meio dele defender.

$\S 1^{\circ}$ A lei definirá os serviços ou atividades essenciais e disporá sobre $\mathrm{o}$ atendimento das necessidades inadiáveis da comunidade.

Da leitura do disposto legal retromencionado, temos que a Lei maior previu que cabe aos grevistas decidir acerca da conveniência e oportunidade, de como e quando exercer a greve. À lei, infraconstitucional, caberia tão somente definir acerca dos serviços e atividades essenciais e quanto as necessidades inadiáveis da população. Logo, constitucionalmente a greve foi tratada como um direito amplo, em razão disso não poderia receber restrições legais. Tal entendimento é partilhado por José Afonso da Silva ${ }^{186}$ e José Carlos Buzanello ${ }^{187}$.

No entanto, a Lei $n^{\circ} 7.783 / 89$, que regulamenta a greve, restringiu este direito, estabelecendo em seu art. $1^{\circ}$, parágrafo único, que o direito de greve deverá ser exercido na forma estabelecida na lei. Em seu art. $2^{\circ}$ prevê, por exemplo que a greve deverá ser temporária e pacífica. Para Buzanello,

\footnotetext{
${ }^{184}$ NASCIMENTO, Amauri Mascaro Curso de direito do trabalho. 29. ed. - São Paulo : Saraiva, 2014. p. 1077.

${ }^{185}$ SILVA, José Afonso. Curso de Direito Constitucional Positivo. São Paulo: Malheiros Editores, 2014, p. 307.

${ }^{186}$ SILVA, José Afonso. Curso de Direito Constitucional Positivo. São Paulo: Malheiros Editores, 2014, p. 307-308.

${ }^{187}$ BUZANELLO, José Carlos. Direito de Resistência Constitucional. Rio de Janeiro: América Jurídica, 2002, p. 220.
} 
esta ocorrência caracteriza que o legislador ordinário contraria a vontade constituinte originária, que previu a ampla liberdade do exercício da greve. $^{188}$

\subsubsection{A Desobediência Civil como Direito Implícito na Constituição}

O direito de resistência decorre das regras e dos princípios constitucionais. A natureza do ius resistendi implícito encontra-se nos princípios oriundos do regime democrático de direito, bem como com os princípios da dignidade da pessoa humana e do pluralismo político, que são fundamentos do Estado democrático. Ainda, conforme previsto no texto constitucional, a partir da integração do ordenamento constitucional de outros direitos e garantias "decorrentes do regime e dos princípios por ela adotados e tratados" $" 189.190$

Conforme já mencionado, para José Carlos Bunzanello, assim como para Maria Garcia, em interpretação do art. $5^{\circ}, \S 2^{\circ}$, da CRFB/88 é possível extrair que: embora o direito de desobediência civil não esteja expressamente previsto no texto constitucional este é admitido no ordenamento pátrio, uma vez que reconhece expressamente em seu art. $5^{\circ}$, $\S 2$, outros direitos e garantias além dos expressos.

Os direitos implícitos na constituição aderem aos direitos e garantias explícitos e aos poderes explícitos do Estado brasileiro.

Para Buzanello, ainda que os direitos implícitos não sejam enunciados por meio de normas expressas, a Constituição lhes atribui valor de integrador do sistema jurídico constitucional pátrio que complementa o rol dos direitos fundamentais. ${ }^{191}$ A partir disso, pode-se depreender que no

\footnotetext{
${ }^{188}$ BUZANELLO, José Carlos. Direito de Resistência Constitucional. Rio de Janeiro: América Jurídica, 2002, p. 220.

${ }^{189}$ Art. $5, \S 2$ da CRFB/88.

${ }^{190}$ BUZANELLO, José Carlos. Direito de Resistência Constitucional. Rio de Janeiro: América Jurídica, 2002, p. 211.

${ }^{191}$ BUZANELLO, José Carlos. Direito de Resistência Constitucional. Rio de Janeiro: América
} 
ordenamento jurídico brasileiro o direito de desobediência civil não só é admitido como possui o status de direito fundamental com todos os valores e proteções a ele inerentes.

A Constituição de 88 não nega a existência de direitos implícitos, desde que harmonizados por ela própria. Logo, toda e qualquer restrição prescindiria de previsão expressa em decorrência direta dos princípios e regras adotados pela Constituição. No entanto, não há na Constituição brasileira proibição ou restrição ao direito de resistência nos termos aqui estudados.

Nesse sentido, permite-se transcrever clássica parêmia "onde a lei não restringe não pode o intérprete fazê-lo". ${ }^{192}$

A resistência implícita se sustenta pelos elementos supracitados, mas, fundamentalmente, pela exegese do art. $5^{\circ}, \S 2$, da CRFB/88 que traz rol dos direitos fundamentais, entre os quais os direitos individuais, ${ }^{193}$ que José Afonso da Silva distingue em três grupos:

$\left.1^{\circ}\right)$ direitos individuais expressos, aqueles explicitamente enunciados nos incisos do art. $5^{\circ} ; 2^{\circ}$ ) direitos individuais implícitos, aqueles que estão subtendidos nas regras de garantias, como direito à identidade pessoal, certos desdobramentos do direito à vida, o direito à atuação geral (art. $5^{\circ}$, II); $3^{\circ}$ ) direitos individuais decorrentes do regime e de tratados internacionais subscritos pelo Brasil, aqueles que não são nem explícita nem implicitamente enumerados, mas provêm ou podem vir a provir do regime adotado, como o direito de resistência, entre outros de difícil caracterização a priori. ${ }^{194}$

Nessa perspectiva, Buzanello identifica o direito de resistência admitido no ordenamento pátrio, a partir das considerações expostas é apenas o individual. No entanto, deve-se ressaltar que não pode o ordenamento jurídico pátrio admitir o ius resistendi apenas nessa expressão, principalmente se decorrente do regime político, que caracteriza uma

\footnotetext{
Jurídica, 2002, p. 211.

${ }^{192}$ BUZANELLO, José Carlos. Direito de Resistência Constitucional. Rio de Janeiro: América Jurídica, 2002, p. 211-212.

${ }^{193}$ BUZANELLO, José Carlos. Direito de Resistência Constitucional. Rio de Janeiro: América Jurídica, 2002, p. 212.

${ }^{194}$ SILVA, José Afonso. Curso de Direito Constitucional Positivo. São Paulo: Malheiros Editores, 2014, p. 197.
} 
expressiva desproporção entre ação e o resultado. Afirma o autor: num cálculo apropriado, a resistência, nesse caso, só terá êxito se for coletiva, como a greve política, a desobediência civil e o direito de revolução". ${ }^{195}$

Maria Garcia, aborda a desobediência civil como instrumento de garantia das prerrogativas da cidadania; como direito fundamental que permite a liberdade-participação no processo decisório do país, pela ação política de viver em sociedade, a cidadania. ${ }^{196}$

Para a autora, em interpretação integrada do art. $1^{\circ}$, II, com o art. 5, $\S 2^{\circ}$, ambos da $\mathrm{CRFB} / 88$, temos o cidadão como titular da coisa pública. A partir disto, o direito de desobediência civil dentro do ordenamento jurídico pátrio permite ao cidadão, a titularidade do poder do Estado, sendo-lhe autorizado promover a alteração ou revogação de lei; ou deixar de atender a lei, ou qualquer ato, que atentem contra a ordem constitucional ou aos seus direitos e garantias fundamentais. ${ }^{197}$

$\mathrm{Na}$ mesma linha de entendimento de Buzanello, Maria Garcia entende que a desobediência civil admite como titulares, tanto o cidadão como um grupo de cidadãos. Ou seja, a desobediência civil pode ser exercida no ordenamento jurídico pátrio de modo individual ou coletivamente. ${ }^{198}$

\subsubsection{Procedimentos Para Requerer a Desobediência Civil}

José Carlos Buzanello, traz em sua obra roteiro para que se requeira o direito de resistência. Para o autor, é fundamental que o postulante conheça a teoria do instituto do direito de resistência, bem como indique as

\footnotetext{
${ }^{195}$ BUZANELLO, José Carlos. Direito de Resistência Constitucional. Rio de Janeiro: América Jurídica, 2002, p. 212.

${ }^{196}$ GARCIA, Maria. Desobediência civil: direito fundamental. São Paulo: Editora Revista dos Tribunais, 2004, p. 295.

${ }^{197}$ GARCIA, Maria. Desobediência civil: direito fundamental. São Paulo: Editora Revista dos Tribunais, 2004, p. 297.

${ }^{198}$ GARCIA, Maria. Desobediência civil: direito fundamental. São Paulo: Editora Revista dos Tribunais, 2004, p. 298.
} 
formas de acesso para que o direito requerido seja efetivado. ${ }^{199}$ Aqui destaco as informações atinentes ao método de se requerer o exercício da desobediência civil em razão de ser o objeto central do presente estudo.

Segundo Buzanello, o exercício da desobediência civil se faz por meio de petição dirigida ao órgão público competente, onde deve-se demonstrar o direito. Deve-se priorizar acordos (negociação, mediação e conciliação).

$\mathrm{Na}$ tentativa de acordo, deve haver o reconhecimento da legitimidade das partes para proteção e defesa de seus próprios direitos. As petições podem ser combinadas com manifestações políticas com repercussão pública de apelo social, as quais, articuladas com audiência pública de autoridade, são fortes mecanismo de pressão política. Ainda, a realização de atos de desobediência civil em áreas sensíveis do Estado, com pedido de tomadas de providências, também são poderosos mecanismos de pressão política; bem como demandar todas as ações e recursos admitidos pelo direito. $^{200}$

Vale mencionar, para Maria Garcia o exercício da desobediência civil pode ser expresso por meio do direito de petição aos poderes públicos; direito fundamental previsto no art. $5^{\circ}$, XXXIV, a, da CRFB/88, o qual se destina à "defesa de direitos ou contra ilegalidade ou abuso de poder.",201

\subsection{Conclusão do Capítulo}

A partir do apresentado no presente capítulo, foi possível constatar que: as promessas assumidas pelo Estado brasileiro, na promulgação da Constituição da República Federal de 1988, não se concretizaram a contento. O país ainda caminha pela implementação e garantia dos direitos

\footnotetext{
${ }^{199}$ BUZANELLO, José Carlos. Direito de Resistência Constitucional. Rio de Janeiro: América Jurídica, 2002, p. 225.

${ }^{200}$ BUZANELLO, José Carlos. Direito de Resistência Constitucional. Rio de Janeiro: América Jurídica, 2002, p. 225.

${ }^{201}$ GARCIA, Maria. Desobediência civil: direito fundamental. São Paulo: Editora Revista dos Tribunais, 2004, p. 298.
} 
fundamentais individuais, políticos, sociais e coletivos estabelecidos na carta constitucional. Além de observância aos princípios e fundamentos do Estado brasileiro instituídos na Carta Magna.

Uma vez que a objeção de consciência, a greve política e a desobediência civil são admitidas no ordenamento jurídico pátrio, a importância dessas formas de exercício do direito de resistência conquistam status de relevância na ordem constitucional. Por serem instrumentos a serviço da população quer individualmente, em pequeno grupo ou em conjunto podem fazer uso destes a fim de exigir por parte do Estado a observância de seus direitos fundamentais; o respeito a ordem jurídica posta e tutelar a observância dos fundamentos e princípios do Estado Democrático de Direito.

Em conclusão, não podemos olvidar do sentido do instituto do direito de resistência no ordenamento pátrio, em especial a desobediência civil, movimento pacífico, e sem violência. A desobediência civil no ordenamento jurídico brasileiro é instrumento garantidor do cumprimento do texto constitucional, da implementação dos direitos e garantias fundamentais, da consolidação do processo democrático e manutenção do Estado Democrático de Direito. 


\section{CONCLUSÃO}

Conforme salientado no início deste trabalho, o instituto do direito de resistência foi objeto de estudo de muitos pesquisadores e comentadores. Em razão das múltiplas contribuições teóricas existentes acerca deste tema, e considerando serem diferentes as abordagens construídas, não foi possível afirmar quando ocorreu a primeira menção do ius resistendi na história. No entanto, aqui se adotou os relatos que apontam que datam de antes de Cristo as primeiras aparições do direito de resistência. Considerando este, presume-se longínqua a estrada que percorre o instituto do direito de resistência, que desde sua origem tem-se aprimorado.

$\mathrm{O}$ aperfeiçoamento do ius resistendi foi demonstrado quando abordamos a possibilidade de seu exercício não apenas de forma coletiva mas também individual. Isso porque, embora a teoria do direito de resistência desenvolvida por John Locke e Thomas Jefferson, tenham proporcionado um grande avanço na história da sociedade, foi através da desobediência civil introduzida por Henry David Thoreau que se possibilitou o exercício do direito de resistência de forma individual ou por grupos menores, rompendo com a sua necessária expressão coletiva, a instrumento somente da maioria.

A obra, o Segundo Tratado Sobre o Governo Civil, de John Locke, hoje é considerada uma das obras mais importantes sobre o modelo liberal, uma vez que o pacto social lockeano possui o consentimento que legitima o estado político posto. No entanto, o mesmo consentimento que fundamenta a nova ordem é legítimo para fazer valer a garantia dos direitos naturais que pretende ter resguardados, de modo que, se violados pelo Estado nasce para o indivíduo o direito de resistência de resguarda-los.

A partir da leitura da Declaração de Independência dos Estados Unidos nota-se que para Jefferson os governantes estão vinculados a assegurar e respeitar os direitos naturais, como a vida, a liberdade e a busca da felicidade. Ainda, para Thomas Jefferson, esses direitos não se 
transmitem ao estado político no momento do pacto, permanecem com os indivíduos e servem como limitação da atuação estatal.

Logo, tanto Locke, como Thomas Jefferson - ambos contratualistas veem o Estado como instituído com o fim de manutenção dos direitos naturais, essenciais ao ser humano, motivo pelo qual os governantes não podem editar leis ou praticar atos que os ameaçem e/ou os violem. Tal premissa pode ser adotada nos dias atuais. O ius resistendi deve ser instrumento de controle do poder estatal, do respeito ao texto constitucional democraticamente instituído e do ordenamento jurídico pátrio. Aqueles, que ao observarem arbitrariedades emanadas do poder estatal, insatisfeitos com a violação de seus direitos naturais podem contra eles insurgir-se.

Além disso, ao analisarmos os feitos de Mahatma Gandhi e Martin Luther King, constatou-se como a desobediência civil, modo de exercício do direito de resistência pacífico e sem violência, pode ser usada a serviço de alteração de leis injustas. Ainda, para aqueles que discordam da manifestação do ius resistendi de forma violenta, a desobediência civil vem se mostrar como método não violento, no entanto, eficaz.

Imperioso ratificar, que a desobediência civil permite que o instituto do direito de resistência seja utilizada individualmente ou a serviço de grupos minoritários. Aqui, me atrevo a destacar que tal caraterística se reveste de enorme especialidade. Sua máxima importância é perceptível em uma sociedade moderna, plural, constituída por diversos grupos minoritários, grupos estes que dividem-se em sub grupos: homens, mulheres, heterossexuais, homossexuais, gays, lésbicas, homens trans, mulheres trans, homens negros, mulheres negras, homens trans negros, etc., tal qual a sociedade brasileira.

Afim de contextualizar o instituto do direito de resistência, sobretudo a desobediência civil, no ordenamento jurídico brasileiro, bem como demonstrar sua aplicação no país, adentramos na análise da Constituição brasileria. 
Verificou-se, que embora o art. $1^{\circ}$ da Constituição da República Federativa do Brasil de 1988, encontre-se averbada promessa de construção de um Estado Democrático de Direito, em pleno 2018, ano em que completa 30 anos, ainda não é possível verificar a completa implementação dos compromissos assumidos. Além disso, sinalizou-se, que após as votações para escolha do próximo ocupante do cargo presidencial do Brasil, paira em parcela da população o temor de possível retrocesso das conquistas até aqui alcançadas diante do atual cenário político que tem gerado revolta e conflitos, entre os integrantes de grupos com ideologias políticas divergentes.

Os candidatos ao cargo presidencial acusaram-se mutuamente de oferecem risco a democracia brasileira, colocando em perigo os direitos e garantias fundamentais asseguradas pela constituição. Uma vez que o direito de resistência é instrumento apto a ser utilizado diante de ameaça estatal ao Estado Democrático de Direito, se mostrou adequada a abordagem deste tema no trabalho.

Posteriormente, demonstrou-se que a objeção de consciência, a greve política e a desobediência civil são admitidas no ordenamento jurídico pátrio, a partir do que se extraiu do texto constitucional. A importância dessas formas de exercício do direito de resistência conquistam status de relevância na ordem constitucional. Por serem instrumentos a serviço da população quer individualmente, em pequeno grupo ou em conjunto podem fazer uso destes a fim de exigir por parte do Estado a observância de seus direitos fundamentais; a obrigatoriedade de edição de leis justas e constitucionais, que não violem seus direitos; o respeito a ordem jurídica posta e tutelar a observância dos fundamentos e princípios do Estado Democrático de Direito.

Em conclusão, não podemos deixar de destacar a importância do instituto da desobediência civil, em especial no ordenamento jurídico brasileiro, sobretudo para aqueles que consideram que a democracia está ameaçada. Uma das formas de exercício do direito de resistência que pode 
ser exercida de forma pacífica e sem violência permite ao resistente manifestar-se a seguimentos específicos da sociedade, como leis, atos e fatos emanados do poder Estatal específicos com manutenção de todo o resto do ordenamento jurídico. Sendo assim instrumentos do cidadão para manutenção do Estado, apto a exigir o cumprimento do texto constitucional, da implementação dos direitos e garantias fundamentais, da consolidação do processo democrático e manutenção do Estado Democrático de Direito.

Assim, afirmamos: a população brasileira tem em suas mãos os instrumentos necessários a fim de controle das atividades dos governantes e da máquina pública. Nunca podemos nos esquecer que "o poder emana do povo", e em caso de arbitrariedades do poder estatal que contrarie a Constituição da República Federativa do Brasil de 1988, lei máxima do ordenamento jurídico pátrio, a qual deve ser observada por todos, nasce para o povo, o titular do poder, o direito de insurgir-se e manifestar-se a fim de manter a ordem democrática. 


\section{BIBLIOGRAFIA}

ATTENBOROUGH, Richard. As Palavras de Gandhi. Tradução A.B. Pinheiro de Lemos. Rio de Janeiro: Record, 1982.

ARENDT, Hannah. Crises Da República. Tradução de José Volkmann. $3^{\text {a }}$ ed. São Paulo: Perspectiva, 2015.

BEDAU, H. A. "On Civil Disobedience", Journal of Philosophy, vol. 58 (1961), pp. 653-661 Apud. RAWLS, John. Uma Teoria da Justiça. Tradução: Almiro Piseta e Lenita M.R. Esteves. São Paulo: Martins Fontes, 2000.

BOBBIO, Norberto; MATTEUCCI, Nicola; PASQUINO, Gianfranco. Dicionário De Política. Coordenação da Tradução João Ferreira. $11^{\mathrm{a}}$.ed. Brasília: Editora UNB, 1997

BOBBIO, Norberto. Teoria Geral Da Política: A Filosofia Política E As Lições Dos Clássicos. 5. Ed. Rio de Janeiro: Campus, 2000.

BOBBIO, Norberto. A Era Dos Direitos. Tradução Carlos Nelson Coutinho. Nova ed. $7^{\text {a }}$. Reimpressão. Rio de Janeiro: Elsevier, 2004.

BRASIL, Constituição da República Federativa do Brasil. Disponível em: <http://www.planalto.gov.br/ccivil_03/constituicao/constituicaocompilado. htm >, Acesso em: 28.10.2018.

BRASIL Código Civil. Disponível em: < http://www.planalto.gov.br/ccivil_03/constituicao/constituicaocompilado.ht m>, Acesso em: 28.10.2018.

BRASIL, Lei 7783/1989. Art. $2^{\circ}$ da Lei no 7.783, de 28 de junho de 1989. Disponível em: <http://www.planalto.gov.br/ccivil_03/LEIS/L7783.htm> Acesso em 10.11.2018.

BRASIL, Lei $8239 . \quad$ Disponível em: http://www.planalto.gov.br/ccivil_03/LEIS/L8239.htm, Acessado em: 31.10.2018.

BUZANELlO, José Carlos. Direito De Resistência Constitucional. Rio de Janeiro: América Jurídica, 2002

BUZANELlo, José Carlos. Direito De Resistência. Disponível em http://www.egov.ufsc.br/portal/sites/default/files/anexos/1199-1213-1PB.pdf. Acesso em: 25.07.2017. 
CANOTILHO, José Joaquim Gomes. Direito Constitucional E Teoria Da Constituição. $6^{\text {a }}$ Edição. Coimbra: Almedina, 1993

CARRILHO, Cristiano. Manual De História Dos Sistemas Jurídicos. Rio de Janeiro: Elsevier, 2009.

CONSTITUIÇÃO DOS ESTADOS UNIDOS DA AMÉRICA. XIV Emenda. Diposnível em: <http://www.uel.br/pessoal/jneto/gradua/historia/recdida/ConstituicaoEUA RecDidaPESSOALJNETO.pdf> Acesso em 17.11.2018

COSTA, Nelson Nery. Ciência Política. $3^{\mathrm{a}}$. edição. Rio de Janeiro: Forense, 2012 ,

COSTA, Nelson Nery. Teoria e Realidade Da Desobediência Civil. $1^{\mathrm{a}}$. edição. Rio de Janeiro: Forense, 1990.

COSTA, Nelson Nery. Ciência Política. $3^{\mathrm{a}}$. edição. Rio de Janeiro: Forense, 2012.

DALLARI, Dalmo de Abreu. Elementos de Teoria Geral do Estado. São Paulo: Saraiva, 2003.

DIREITOS FUNDAMENTAIS. As Piores Decisões Proferidas. Disponível em:< https://direitosfundamentais.net/2008/10/23/as-piores-decisoes-dasuprema-corte-dos-eua-ii-caso-plessy-vs-ferguson/>. Acesso em: 14.06.2018.

FRIED, Reis. Curso Analítico De Direito Constitucional E De Teoria Geral Do Estado. Rio de Janeiro: Forense, 2005.

GARCIA, Maria. Desobediência Civil: Direito Fundamental. São Paulo: Editora Revista dos Tribunais, 2004.

JEFFERSON, Thomas. A Declaração Da Independência Dos Estados Unidos Da América. Disponível em <http://www.uel.br/pessoal/jneto/gradua/historia/recdida/declaraindepeEU AHISJNeto.pdf>acessado em: 02/07/17.

JUSBRASIL. Apelação 0003983-03.2009.8.26.0160. Disponível em: https://tj-sp.jusbrasil.com.br/jurisprudencia/21996433/apelacao-apl39830320098260160-sp-0003983-0320098260160-tjsp/inteiro-teor110489935 ?ref=juris-tabs, Acessado em: 31.10.2018.

KELSEN, Hans. Teoria Geral Do Direito e Do Estado. São Paulo: Martins Fontes, 2000, p. 314-315. 
KING JR, Martin Luther. A Autobiografia de Martin Luther King Jr. Organização Clayborne Carson. Tradução de Carlos Alberto Medeiros. $1^{\mathrm{a}}$ edição. Rio de Janeiro: Zahar, 2014.

LAFER, Celso. A Reconstrução Dos Direitos Humanos: Um Diálogo Com O Pensamento De Hannah Arendt. São Paulo: Companhia das Letras, 1991.

LOCKE, John. Segundo Tratado Sobre o Governo Civil. Tradução: Marsely de Marco Dantas. São Paulo: EDIPRO, 2014.

MARTINS, Carlos Estevan e MONTEIRO, João Paulo. Locke: Vida e Obras. In: LOCKE, John. Os Pensadores: Locke, op. cit., pp. XV/XVI Apud COSTA, Nelson Nery. Ciência Política. $3^{\text {a }}$. edição. Rio de Janeiro: Forense, 2012, p. 236-237.

MIGUEL, Reale. Teoria Do Direito E Do Estado. São Paulo: Martins, 1960, in DALLARI, Dalmo de Abreu. Elementos de Teoria Geral do Estado. São Paulo: Saraiva, 2003.

MIRANDA, Daniel Moreira. Apresentação: Os Dois Tratados Sobre O Governo In: LOCKE, John. Segundo Tratado Sobre O Governo Civil. Tradução: Marsely de Marco Dantas. São Paulo: EDIPRO, 2014.

MIRANDA, Daniel Moreira. Introdução: Pensamento Político De Thoreau. In: THOREAU, Henry David. A Desobediência Civil. Tradução: Daniel Moreira Miranda. São Paulo: EDIPRO, 2016.

NAÇÕES UNIDAS. Disponível em: https://nacoesunidas.org/wpcontent/uploads/2018/10/DUDH.pdf > Acessado em: 31.10.2018.

NASCIMENTO, Amauri Mascaro. Curso De Direito Do Trabalho. 29. ed. - São Paulo : Saraiva, 2014.

PAUPÉRIO, Machado. O Direito Político De Resistência. Rio de Janeiro: Forense, 1978, p. 11-13 apud GARCIA, Maria. Desobediência Civil: Direito Fundamental. São Paulo: Editora Revista dos Tribunais, 2004.

PAUPÉRIO, Machado. O Direito Político De Resistência. Rio de Janeiro: Forense, 1978.

RAWLS, John. Uma Teoria da Justiça. Tradução: Almiro Piseta e Lenita M.R. Esteves. São Paulo: Martins Fontes, 2000.

SPINOZA, Baruch. Ética. Tradução de Tomaz Tadeu. Belo Horizonte: Autêntica Editora, 2009.

SILVA, José Afonso. Curso De Direito Constitucional Positivo. São Paulo: Malheiros Editores, 2014. 
SÓFOCLES. Antígone. Tradução de J. B. Mello e Souza. Versão para eBook, $2005 . \quad$ Disponível em $\langle$ http://direitorio.fgv.br/sites/direitorio.fgv.br/files/antigona.pdf>. Acesso em: 11.07.2017.

SUPREMO TRIBUNAL FEDERAL. Disponível em: < http://redir.stf.jus.br/paginadorpub/paginador.jsp?docTP=AC\&docID=3753 24>, Acesso em: 28.10.2018.

SUPREMO TRIBUNAL FEDERAL Disponível em: $<$ http://redir.stf.jus.br/paginadorpub/paginador.jsp?docTP=AC\&docID=555 517>, Acesso em: 28.10.2018.

SUPREMO TRIBUNAL FEDERAL. HC 94.016, Rel. Min. Celso de Mello, julgamento em 16-9-2008, Segunda Turma, DJE de 27-2-2009.

SUPREMO TRIBUNAL FEDERAL Disponível em: https://stf.jusbrasil.com.br/jurisprudencia/15809827/mandado-deseguranca-ms-28981-df-stf, Acessado em: 31.10.2018.

THOREAU, Henry David. A Desobediência Civil. Tradução: Daniel Moreira Miranda. São Paulo: EDIPRO, 2016.

UNIVERSIDADE ESTADUAL DE LONDRINA. A Constituição dos Estados Unidos da América. Disponível em: <http://www.uel.br/pessoal/jneto/gradua/historia/recdida/ConstituicaoEUA RecDidaPESSOALJNETO.pdf> Acessado em: 29.10.2018. 